Article

\title{
Highly Enhanced Catalytic Stability of Copper by the Synergistic Effect of Porous Hierarchy and Alloying for Selective Hydrogenation Reaction
}

\author{
Hao Yuan ${ }^{1,2}$, Zhao Wang ${ }^{1,2}, * \mathbb{0}$, Shunjing Jin ${ }^{3}$, Shanshan Xiao ${ }^{2}$, Siming Liu ${ }^{2}$, Zhiyi Hu ${ }^{2}$, Lihua Chen ${ }^{2}$ \\ and Baolian $\mathrm{Su}^{2,4, *(D)}$ \\ 1 Foshan Xianhu Laboratory of the Advanced Energy Science and Technology Guangdong Laboratory, \\ Guangdong Laboratory, Xianhu Hydrogen Valley, Foshan 528200, China; 303934@whut.edu.cn \\ 2 Laboratory of Living Materials, The State Key Laboratory of Advanced Technology for Material Synthesis and \\ Processing, Wuhan University of Technology, Wuhan 430070, China; 303768@whut.edu.cn (S.X.); \\ 317580@whut.edu.cn (S.L.); Zhiyi.hu@whut.edu.cn (Z.H.); chenlihua@whut.edu.cn (L.C.) \\ 3 Xiangyang Polytechnic, Xiangyang 441050, China; 317150@whut.edu.cn \\ 4 Laboratory of Inorganic Materials Chemistry (CMI), University of Namur, 61 Rue de Bruxelles, \\ B-5000 Namur, Belgium \\ * Correspondence: zhao.wang@whut.edu.cn (Z.W.); bao-lian.su@unamur.be (B.S.)
}

check for updates

Citation: Yuan, H.; Wang, Z.; Jin, S.; Xiao, S.; Liu, S.; Hu, Z.; Chen, L.; Su, B. Highly Enhanced Catalytic Stability of Copper by the Synergistic Effect of Porous Hierarchy and Alloying for Selective Hydrogenation Reaction. Catalysts 2022, 12, 12.

https://doi.org/10.3390/

catal12010012

Academic Editor: Ivan

V. Kozhevnikov

Received: 6 December 2021

Accepted: 21 December 2021

Published: 24 December 2021

Publisher's Note: MDPI stays neutral with regard to jurisdictional claims in published maps and institutional affiliations.

Copyright: (C) 2021 by the authors. Licensee MDPI, Basel, Switzerland. This article is an open access article distributed under the terms and conditions of the Creative Commons Attribution (CC BY) license (https:// creativecommons.org/licenses/by/ $4.0 /)$.

\begin{abstract}
Supported copper has a great potential for replacing the commercial palladium-based catalysts in the field of selective alkynes/alkadienes hydrogenation due to its excellent alkene selectivity and relatively high activity. However, fatally, it has a low catalytic stability owing to the rapid oligomerization of alkenes on the copper surface. In this study, $2.5 \mathrm{wt} \% \mathrm{Cu}$ catalysts with various $\mathrm{Cu}: \mathrm{Zn}$ ratios and supported on hierarchically porous alumina (HA) were designed and synthesized by deposition-precipitation with urea. Macropores (with diameters of $1 \mu \mathrm{m}$ ) and mesopores (with diameters of $3.5 \mathrm{~nm}$ ) were introduced by the hydrolysis of metal alkoxides. After in situ activation at $350{ }^{\circ} \mathrm{C}$, the catalytic stability of $\mathrm{Cu}$ was highly enhanced, with a limited effect on the catalytic activity and alkene selectivity. The time needed for losing $10 \%$ butadiene conversion for Cu1Zn3/HA was $40 \mathrm{~h}$, which is 20 times higher than that found for $\mathrm{Cu} / \mathrm{HA}(\sim 2 \mathrm{~h})$, and 160 times higher than that found for $\mathrm{Cu} /$ bulky alumina $(0.25 \mathrm{~h})$. It was found that this type of enhancement in catalytic stability was mainly due to the rapid mass transportation in hierarchically porous structure (i.e., four times higher than that in bulky commercial alumina) and the well-dispersed copper active site modified by Zn, with identification by STEM-HAADF coupled with EDX. This study offers a universal way to optimize the catalytic stability of selective hydrogenation reactions.
\end{abstract}

Keywords: hierarchically porous structure; selective hydrogenation reaction; unsaturated hydrocarbons; copper-zinc alloy; synergistic effect; 1,3-butadiene

\section{Introduction}

Alkenes, especially $C_{2}-C_{4}$ olefins with a purity higher than $99.999 \%$, are fundamental chemicals in the synthesis of polymers, surfactants and other products related to organic chemical industry by catalytic polymerization reactions [1]. In general, alkenes are mainly obtained from the hydrocracking of crude oil [2], which also results in small amounts of alkyne and diene impurities, such as $2-8 \%$ of propyne and propadiene in propene cuts [3] and $0.3-0.8 \%$ of butyne and butadiene in butenes cuts [4]. These impurities can poison the catalysts used for alkene polymerization and terminate the polymerization reaction by transforming catalysts to a stable intermediate [5,6]-i.e., 2-butyne and butadiene impurities react with $\mathrm{Cp}_{2}{ }_{2} \mathrm{ScCH}_{3}\left(\mathrm{Cp}^{*}=\eta^{5}-\mathrm{C}_{5} \mathrm{Me}_{5}\right)$ catalyst, forming a stable $\mathrm{Cp}_{2}{ }_{2} \mathrm{Sc}\left(\mathrm{CH}_{3}\right)=\mathrm{C}\left(\mathrm{CH}_{3}\right)_{2}$ product [7]. Thus, the concentration of alkyne and diene impurities must be reduced to below $0.001 \%$. The selective hydrogenation reaction, which can selectively convert the impurities into valuable alkene raw materials, is widely used in 
industry. The classical catalyst for such reaction is the Lindlar catalyst [8], which consists of a palladium active site and a calcium carbonate support. However, in order to obtain a high alkene selectivity, the catalytic activity of the palladium is usually modified by some poison (e.g., lead, quinoline etc.). Moreover, noble-metal-based bi-metallic catalysts, e.g., $\mathrm{Pd}-\mathrm{Ag} / \mathrm{Al}_{2} \mathrm{O}_{3}$ synthesized by the Süd-Chemie company [9-11], are the main commercial catalyst, but their high price ( USD 10,000 kg-1) and low selectivity to alkenes $(<20 \%$ at full conversion) [12] largely limit their further utilization. Thus, the exploration of alternative catalysts with a high catalytic performance and low cost remains a great challenge in the current alkenes industry [13].

Copper is one of the best candidates for selective hydrogenation reactions due to its low cost and rather high catalytic activity and selectivity to alkenes. The price of copper-based catalysts is more than 1000 times lower than that of commercialized Pdbased catalysts. Compared with palladium-based catalysts, metallic $\mathrm{Cu}$ has shown a high selectivity to alkenes $(>90 \%$ at full alkyne/diene conversion $[14,15])$ and moderate full alkyne/diene conversion temperature $\left(75 \sim 150{ }^{\circ} \mathrm{C}\right.$ [14-17]). In addition, copper has also shown an advanced catalytic property among non-noble metals [18] (e.g., $\mathrm{Ni}, \mathrm{Co}, \mathrm{Fe}$ ) in terms of its selectivity to alkenes at full alkyne/diene conversion [19-21] and catalytic activity [22,23]. However, the main barrier to the commercialization of $\mathrm{Cu}$ catalysts is its rapid deactivation during selective hydrogenation reactions [24]. Specifically, monometallic copper supported on $\mathrm{TiO}_{2}$ for the selective hydrogenation of butadiene has shown a butadiene conversion from $100 \%$ to below $20 \%$ in less than $3 \mathrm{~h}$ on stream [15], which is far from the requirement in industry. Numerous studies have focused on the exploration of deactivation mechanisms since the 1990s $[25,26]$. The loss of activity was mainly attributed to the coverage of catalytic active sites by the accumulation of foulants [5], which are $C_{8}$ to $C_{22}$ oligomers formed by the oligomerization of neighboring intermediate carbenes via metallocycles [27]. Developing Cu-based catalysts with a high catalytic stability is always a hot research topic in alkenes industry.

Tuning copper's active site could be an efficient way to obtain a high catalytic stability. By increasing the copper atom dispersion from $12.3 \%$ (i.e., nanoparticle) to $100 \%$ (i.e., atomic dispersion) on an alumina support, Lu et al. [16] observed an increase in the catalytic stability from 25 to $40 \mathrm{~h}$ for mono-metallic copper, with a decrease of the foulant accumulation from $30 \mathrm{wt} \%$ to $3.3 \mathrm{wt} \%$ during the acetylene hydrogenation reaction. A similar result was also verified by Ma et al. [17], who developed atomically dispersed $\mathrm{Cu}$ on nanodiamond-graphene that shows a stable acetylene conversion of $95 \%$ over $60 \mathrm{~h}$ of isothermal reaction. However, the synthesis of atomically dispersed $\mathrm{Cu}^{0}$ remains a great challenge, as the $\mathrm{Cu}^{0}$ atom is unstable and tends to be either aggregated into $\mathrm{Cu}$ nanoparticles or positively charged, by transferring electrons to its support (i.e., it shows a strong metal-support interaction). Alloying copper with other metal assistants [28] (e.g., Au [29], $\mathrm{Pd}$ [30-32], Pt [33] etc.) has been proposed to solve this drawback. Using a density functional theory calculation, Nørskov et al. [13] predicted that $\mathrm{Cu}-\mathrm{Zn}$ alloy (e.g., Cu1Zn1) could be a potential replacement for current Pd-based catalysts. Recently, Louis et al. [34] experimentally verified that alloying $\mathrm{Cu}$ with small amounts of $\mathrm{Zn}$ (i.e., $\mathrm{Cu}_{3} \mathrm{Zn}_{1}$ alloy and intermediate $\mathrm{Cu}_{0.9} \mathrm{Zn}_{0.1}$ alloy) strongly improves the catalytic stability of $\mathrm{Cu}$ in the selective hydrogenation of butadiene, with butadiene conversion decreased from $100 \%$ to $~ 80 \%$ after $20 \mathrm{~h}$ of reaction for bi-metallic $\mathrm{Cu}-\mathrm{Zn}$ catalysts. However, the specific surface area of the support is always a limitation, as it produces either a rather low $\mathrm{Cu}$ loading for atomically dispersed $\mathrm{Cu}$ catalysts or large metallic particles for $\mathrm{Cu}$-based bi-metallic catalysts. Both decrease the apparent catalytic activity of supported $\mathrm{Cu}$-based catalysts, with a high full alkyne/alkadiene conversion temperature.

Increasing the specific surface area of the support by introducing a porous structure shows great promise, as it could improve the $\mathrm{Cu}$ loading without affecting the $\mathrm{Cu}$ dispersion. For example, Ma et al. [35] synthesized ordered hierarchical porous silica (HPS), with a specific surface area above $600 \mathrm{~m}^{2} \mathrm{~g}^{-1}$ as the support for $\mathrm{Cu}$ catalysts. The supported $\mathrm{Cu}$ particles were confined to the porous structure, with a size smaller than $5 \mathrm{~nm}$ at $20 \mathrm{wt} \%$ 
of $\mathrm{Cu}$ loading. The catalysts showed a rather high catalytic activity and stability in the hydrogenation of dimethyl adipate (i.e., a turnover frequency $\sim 0.72 \mathrm{~h}^{-1}$ and no decrease in dimethyl adipate conversion after $120 \mathrm{~h}$ of reaction). Moreover, they found the pore size in catalysts had a significant effect on the mass transportation of dimethyl adipate reactants and could limit the hydrogenation reaction. We have recently synthesized monometallic $\mathrm{Cu}$ supported by hierarchically porous carbon (HPC) with a $\mathrm{Cu}$ loading as high as $40-50 \mathrm{wt} \%$ by the in situ carbonization of HKUST-1 (with a surface area of $1599 \mathrm{~m}^{2} \mathrm{~g}^{-1}$ ) at a high temperature $\left(>400{ }^{\circ} \mathrm{C}\right)$ [36]. The special macro-mesoporous structure of the carbon support with well-confined $\mathrm{Cu}$ nanoparticles in $\mathrm{Cu} / \mathrm{HPC}$ provided a rather high catalytic performance-i.e., butadiene conversion stayed at $100 \%$ for over $120 \mathrm{~h}$ of time on stream-showing that combining a porous hierarchy with a high surface area is an efficient way to improve the catalytic stability of mono-metallic $\mathrm{Cu}$ catalyst. However, the catalytic stability was still restricted by the utilization of mono-metallic $\mathrm{Cu}$ active sites, which could be further improved by the synthesis of Cu-based bi-metallic active sites on a hierarchically porous support.

Therefore, tuning the intrinsic properties of copper atoms by alloying on the surface of a hierarchically porous support could be a promising way to obtain a $\mathrm{Cu}$-based catalyst with a highly enhanced catalytic stability. Compared with the previous carbon supports [36], alumina shows great advantages as a support for metallic catalysts due to its low cost and high thermal stability. Moreover, Louis et al. [34] mainly focused on Cu-rich bimetal $\mathrm{Cu}-$ $\mathrm{Zn} / \mathrm{TiO}_{2}$ catalysts that only produce $\mathrm{Cu}$-rich $\mathrm{Cu}-\mathrm{Zn}$ alloys, which are not highly consistent with the predictions (i.e., Cu1Zn1 alloy) of Nørskov et al. [13]. In this study, bi-metallic $\mathrm{Cu}-\mathrm{Zn}$ catalysts with $2.5 \mathrm{wt} \%$ of $\mathrm{Cu}$ and an excess of $\mathrm{Zn}$ supported by hierarchically porous $\mathrm{Al}_{2} \mathrm{O}_{3}$ were synthesized for the selective butadiene hydrogenation. $\mathrm{Zn}$ is inert for selective hydrogenation and acts as catalytic assistant. The study on the synergistic effect of a porous hierarchy and alloying on enhancing catalytic performance was carried out on the copper catalysts, with various $\mathrm{Cu}: \mathrm{Zn}$ ratios and different porous structures. This study provides a powerful and universal way to optimize catalytic performance in both homogeneous and heterogeneous reactions.

\section{Results and Discussion}

\subsection{Preparation of the Hierarchically Porous Alumina Supported Bimetallic $\mathrm{Cu}-\mathrm{Zn}$ Catalysts}

The hierarchically porous structure in the alumina support was self-constructed by the rapid hydrolysis and condensation of metal alkoxides in the absence of any templates (Figure 1). Specifically, once aluminum sec-butoxide (TBOA) was dropped into an aqueous solvent, it rapidly hydrolyzed to hydroxy-alumina, with the hydrolysis and condensation reaction as follows [37,38]:

$\mathrm{Al}\left(\mathrm{C}_{4} \mathrm{H}_{9} \mathrm{O}\right)_{3}+\mathrm{xH}_{2} \mathrm{O} \rightarrow \mathrm{Al}\left(\mathrm{C}_{4} \mathrm{H}_{9} \mathrm{O}\right)_{3-\mathrm{x}}(\mathrm{OH})_{\mathrm{x}}+\mathrm{xC}_{4} \mathrm{H}_{9} \mathrm{OH} \rightarrow \mathrm{AlOOH}+3 \mathrm{C}_{4} \mathrm{H}_{9} \mathrm{OH}$ (hydrolysis reaction)

$2 \mathrm{Al}\left(\mathrm{C}_{4} \mathrm{H}_{9} \mathrm{O}\right)_{3-\mathrm{x}}(\mathrm{OH})_{x} \rightarrow(\mathrm{HO})_{x-1}\left(\mathrm{C}_{4} \mathrm{H}_{9} \mathrm{O}\right)_{3-\mathrm{x}} \mathrm{Al}-\mathrm{O}-\mathrm{Al}\left(\mathrm{C}_{4} \mathrm{H}_{9} \mathrm{O}\right)_{3-\mathrm{x}}(\mathrm{OH})_{\mathrm{x}-1}+\mathrm{H}_{2} \mathrm{O}$ (condensation reaction)

Moreover, during the solidification of the hydroxy-alumina by the hydrolysis and condensation reaction, a large amount of sec-butyl alcohol (i.e., alcohol / $\mathrm{Al}$ molar ratio $=3$ ) was rapidly formed and blow-off from the interior part of the TBOA toward the surrounding acetonitrile/water solvent. Meanwhile, the structure of the solid phase was modified by the fast fluxion of the sec-butyl alcohol, with an accumulation of the layered hydroxyalumina (i.e., $\mathrm{AlOOH}$ ) around the liquid sec-butyl alcohol [38,39]. Finally, after removing the liquid solvent phase by drying at $60{ }^{\circ} \mathrm{C}$, followed by calcination at $550{ }^{\circ} \mathrm{C}$ in air for $3 \mathrm{~h}$, a hierarchically porous structure was constructed with $\gamma-\mathrm{Al}_{2} \mathrm{O}_{3}$ support, with XRD patterns presented in Figure S1. The morphology of the macropores was identified by SEM (Figure 1), which shows macropores with a diameter of $1 \mu \mathrm{m}$ and a wall of layered $\gamma-\mathrm{Al}_{2} \mathrm{O}_{3}$. 

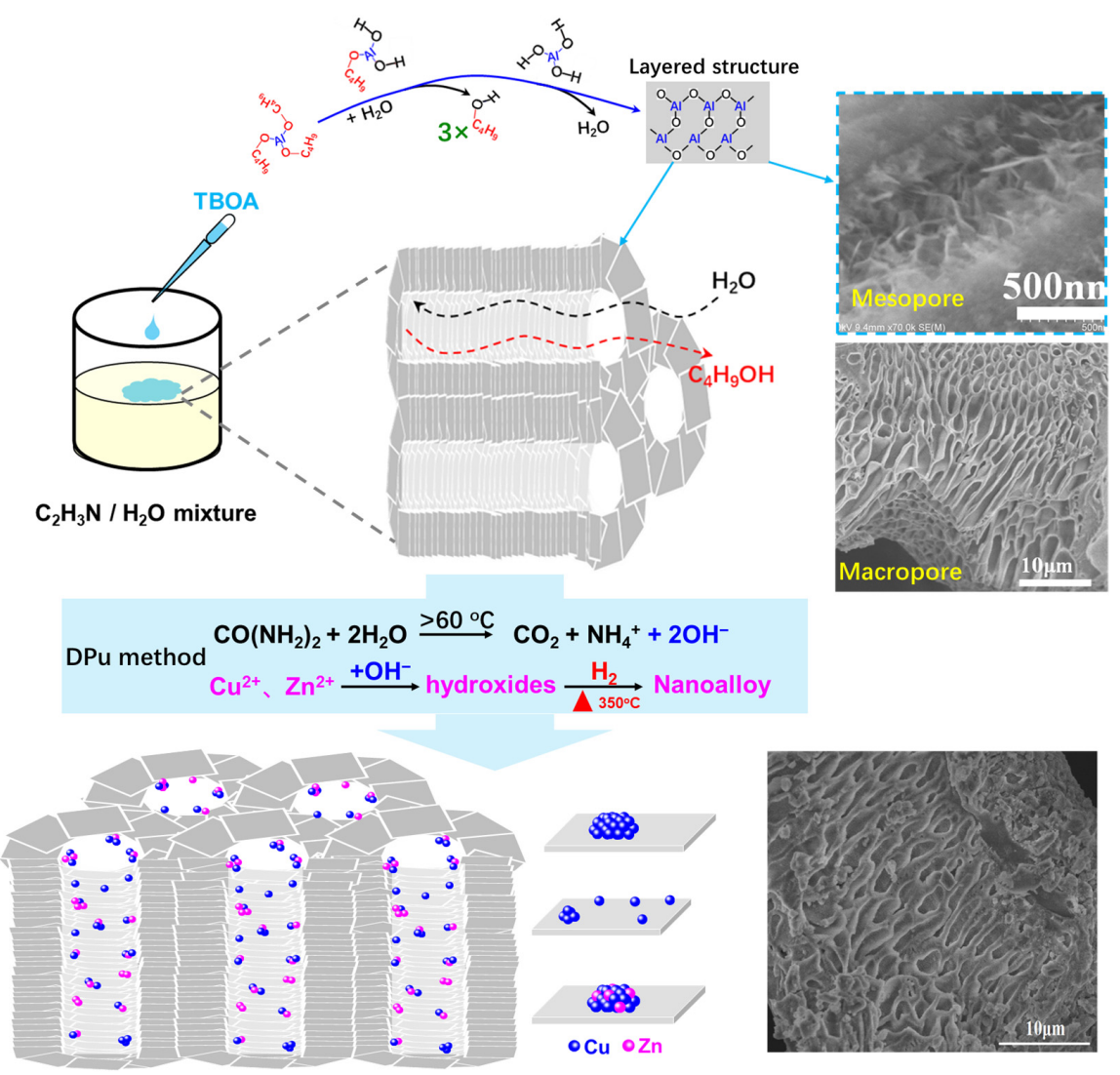

Figure 1. Illustration of the synthesis of a hierarchically porous alumina supported bi-metallic $\mathrm{Cu}-\mathrm{Zn}$ catalyst.

The deposition-precipitation of $\mathrm{Cu}^{2+}$ and $\mathrm{Zn}^{2+}$ on the surface of hierarchically porous $\gamma-\mathrm{Al}_{2} \mathrm{O}_{3}(\mathrm{HA})$ was realized by using urea as the precipitant. Urea, after dissolving in water, gradually decomposes at a temperature above $60^{\circ} \mathrm{C}$, with the formation of hydroxyl (i.e., $\mathrm{OH}^{-}$). The increase of the $\mathrm{OH}^{-}$concentration in solution promotes the depositionprecipitation of metal ions by the formation of hydroxides, and also by the modification of the surface charge of the support to create an electrostatic adsorption [40]. The metal loadings of $\mathrm{Cu}$ and $\mathrm{Zn}$ on HA are summarized in Table 1. A Cu loading of around $2.3 \mathrm{wt} \%$ was obtained for all the samples. As for the Cu1Zn1/HA, Cu1Zn3/HA and Cu1Zn5/HA samples, the $\mathrm{Cu} / \mathrm{Zn}$ atomic ratios from our experimental analysis were 1:0.92, 1:2.3 and 1:3.6. The lower $\mathrm{Zn}$ loading than the nominal one was due to the higher solubility of zinc hydroxide $\left(4.17 \times 10^{-17} \mathrm{~mol} \mathrm{~L}^{-1}\right)$ than that of copper hydroxide $\left(2.0 \times 10^{-17} \mathrm{~mol} \mathrm{~L}^{-1}\right)$ [34]. Bi-metal $\mathrm{Cu}-\mathrm{Zn}$ catalysts, with various $\mathrm{Cu}: \mathrm{Zn}$ ratios, were successfully synthesized.

\subsection{The Porous Hierarchy in $\mathrm{Cu}-\mathrm{Zn}$ Supported on Hierarchically Porous $\gamma-\mathrm{Al}_{2} \mathrm{O}_{3}$}

Figure 2a shows the nitrogen adsorption-desorption isotherms of all the prepared samples. Both HA and $\mathrm{Cu}-\mathrm{Zn} / \mathrm{HA}$ had a VI type of hysteresis loop in the relative pressures $\left(\mathrm{P} / \mathrm{P}_{0}\right)$ in the range of 0.4 1.0, indicating the presence of abundant mesopores in the samples. Based on the desorption behavior (dotted line in Figure 2a), the shape of the mesopores in the sample could be slits [41], formed by the stacking of the alumina nanosheet (Figure 1). Table 1 includes the textural properties of all the prepared samples. Specifically, the total surface area of pure HA was $394 \mathrm{~m}^{2} \mathrm{~g}^{-1}$. The deposition of $\mathrm{Cu}-\mathrm{Zn}$ by DPu brought a decrease in the total surface area to 355, 315, 291 and $259 \mathrm{~m}^{2} \mathrm{~g}^{-1}$ for $\mathrm{Cu} / \mathrm{HA}$, Cu1Zn1/HA, Cu1Zn3/HA and Cu1Zn5/HA, respectively. The mesopore distribution in the pure HA showed a main peak centered at $3.8 \mathrm{~nm}$, with a shoulder at $4.2 \mathrm{~nm}$ (Figure $2 \mathrm{~b}$ ). After the deposition of $\mathrm{Cu}$, the diameter of the mesopores slightly decreased to $3.7 \mathrm{~nm}$. Moreover, with an increase of the $\mathrm{Zn}$ loading from $0 \mathrm{wt} \%$ to $5.3 \mathrm{wt} \%$, the mesopore size 
gradually decreased from $3.7 \mathrm{~nm}$ to $3.5 \mathrm{~nm}$. In addition, the deposition of $\mathrm{Cu}$ brought a $15.7 \%$ decrease in the total pore volume of the HA: i.e., $0.57 \mathrm{~cm}^{3} \mathrm{~g}^{-1}$ and $0.48 \mathrm{~cm}^{3} \mathrm{~g}^{-1}$ for $\mathrm{HA}$ and $\mathrm{Cu} / \mathrm{HA}$, respectively. As for $\mathrm{Cu}-\mathrm{Zn} / \mathrm{HA}$, the total pore volume showed a $33.3 \%$ to $42 \%$ decrease with the increase of the $\mathrm{Zn}$ loading from $2.2 \mathrm{wt} \%$ to $5.3 \mathrm{wt} \%$ : i.e., 0.38 and $0.33 \mathrm{~cm}^{3} \mathrm{~g}^{-1}$ for Cu1Zn1/HA and Cu1Zn3/HA, respectively (Table 1). Specially, as for $\mathrm{Cu} 1 \mathrm{Zn} 5 / \mathrm{HA}$, the dramatic decrease in the total surface area with an unchanged total pore volume and diameter indicate that the macroporous structure might have been slightly destroyed, as some fragments of alumina can be observed in SEM images (Figures S2 and S3). The decrease of the pore size and pore volume with the $\mathrm{Cu}-\mathrm{Zn}$ loading indicates that the deposited $\mathrm{Cu}$ and $\mathrm{Zn}$ species were mainly located in the mesopores of the HA. The commercial alumina ( $\mathrm{CA}$ ) and $\mathrm{Cu} / \mathrm{CA}$ showed no hysteresis loop, indicating their poorly porous nature. Moreover, the specific surface areas were 3 and $4 \mathrm{~m}^{2} \mathrm{~g}^{-1}$ for $\mathrm{CA}$ and $\mathrm{Cu} / \mathrm{CA}$, respectively. Thus, based on the characterization above, $\mathrm{Cu}-\mathrm{Zn} / \mathrm{HA}$ samples contained hierarchically macro-mesoporous structures, with macropore size of $1 \mu \mathrm{m}$ and mesopore size of $3.5 \mathrm{~nm}$. Moreover, $\mathrm{Cu}$ and $\mathrm{Zn}$ were mainly deposited in the mesopores of the HA.

Table 1. Metal loadings and textural properties of as-prepared $\mathrm{Cu}-\mathrm{Zn} /$ alumina catalysts.

\begin{tabular}{|c|c|c|c|c|c|c|c|c|c|}
\hline \multirow{3}{*}{ Sample } & \multicolumn{3}{|c|}{ Theoretical Values } & \multicolumn{3}{|c|}{ Experimental Values } & \multirow{3}{*}{$\begin{array}{l}\text { Total BET Surface } \\
\text { Area }\left(\mathrm{m}^{2} / \mathrm{g}\right)\end{array}$} & \multirow{3}{*}{$\begin{array}{c}\text { Total Pore } \\
\text { Volume }\left(\mathrm{cm}^{3} / \mathrm{g}\right)\end{array}$} & \multirow{3}{*}{$\begin{array}{c}\text { Meso Pore } \\
\text { Diameter }(\mathrm{nm})\end{array}$} \\
\hline & \multicolumn{2}{|c|}{ Loading (wt $\%)$} & \multirow{2}{*}{$\mathrm{Cu}: \mathrm{Zn}$} & \multicolumn{2}{|c|}{ Loading (wt $\%)$} & \multirow{2}{*}{$\mathrm{Cu}: \mathrm{Zn}$} & & & \\
\hline & $\mathrm{Cu}$ & $\mathrm{Zn}$ & & $\mathrm{Cu}$ & $\mathrm{Zn}$ & & & & \\
\hline HA & - & - & - & - & - & - & 394 & 0.57 & $3.8,4.2$ \\
\hline $\mathrm{Cu} / \mathrm{HA}$ & 2.5 & 0 & $1: 0$ & 2.3 & 0 & $1: 0$ & 355 & 0.48 & 3.7 \\
\hline Cu1Zn1/HA & 2.5 & 2.5 & $1: 1$ & 2.4 & 2.2 & $1: 0.9$ & 315 & 0.38 & 3.7 \\
\hline $\mathrm{Cu} 1 \mathrm{Zn} 3 / \mathrm{HA}$ & 2.5 & 7.5 & $1: 3$ & 2.3 & 5.3 & $1: 2.3$ & 291 & 0.33 & 3.5 \\
\hline Cu1Zn5/HA & 2.5 & 12.5 & $1: 5$ & 2.3 & 8.2 & $1: 3.6$ & 259 & 0.33 & 3.5 \\
\hline $\mathrm{Cu} / \mathrm{CA}$ & 2.5 & 0 & 1:0 & 2.3 & 0 & $1: 0$ & 4 & - & - \\
\hline CA & - & - & - & - & - & - & 3 & - & - \\
\hline
\end{tabular}

(a)

(c)
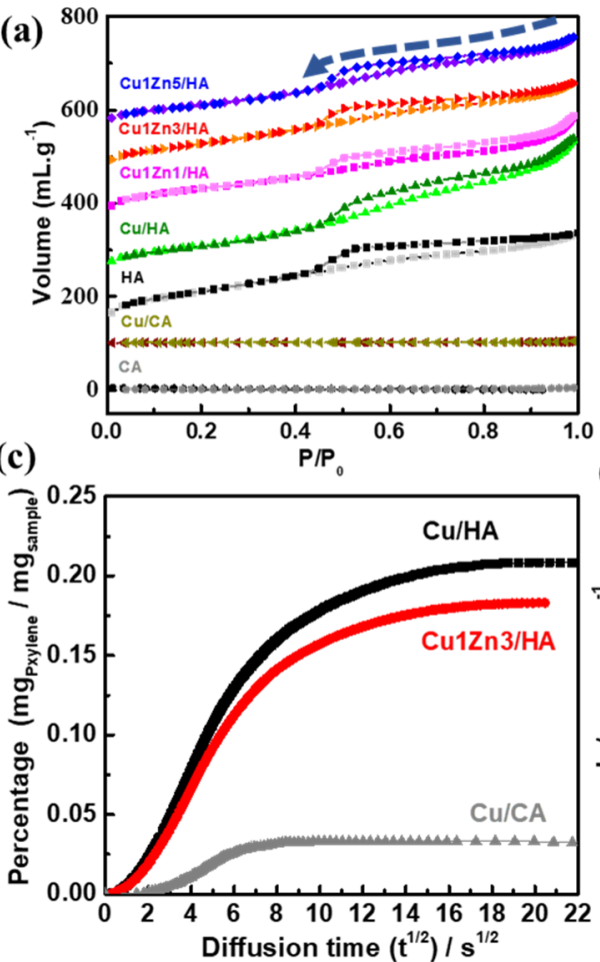

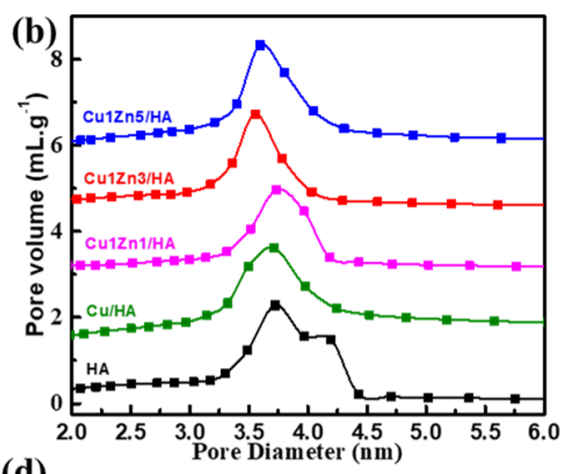

(d)

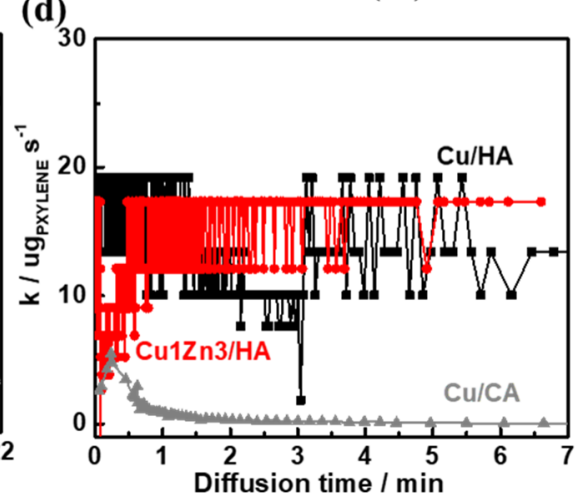

Figure 2. $\mathrm{N}_{2}$ adsorption-desorption isotherms (a) and pore size distribution curves (b) of $\mathrm{Cu}$ $\mathrm{Zn} / \mathrm{Al}_{2} \mathrm{O}_{3}$ samples; the adsorption percentage (c) and the adsorption kinetic constant (d) of p-xylene as a function of diffusion time at $50{ }^{\circ} \mathrm{C}$. 
The mass transportation accelerated by introducing a hierarchically porous structure into the alumina-supported copper catalyst was evaluated by the intelligent gravimetric analyzer (IGA) using p-xylene as the probe molecular. In this method, the probe molecular diffuses into the porous system and adsorbs onto the surface of materials, resulting in a weight increase. In Figure 2c, it can be found that the weight percentage of adsorbates on the $\mathrm{Cu} /$ bulky commercial alumina $(\mathrm{Cu} / \mathrm{CA})$ showed a slow increase to $0.05 \%$ in the first $6 \mathrm{~s}^{1 / 2}$, finally keeping constant at $0.05 \%$. With a similar $\mathrm{Cu}$ loading, the weight percentage of adsorbates on $\mathrm{Cu} / \mathrm{HA}$ rapidly increased above $0.12 \%$ in the first $6 \mathrm{~s}^{1 / 2}$, followed by a stabilization at $0.2 \%$. Moreover, the addition of $\mathrm{Zn}$ slightly decreased the weight percentage of adsorbates; e.g., 0.18\% was observed for $\mathrm{Cu} 1 \mathrm{Zn} 3 / \mathrm{HA}$. As for a constant material (i.e., alumina), the final weight of adsorbates was decided by the surface area of the samples. More importantly, the property of mass transportation in the samples was evaluated by the rate of the weight evolution as a function of the adsorption time. The adsorption kinetic constant $(\mathrm{k})$ for these samples was calculated by the following formula [42] (Figure 2d):

$$
\mathrm{m}_{(\mathrm{t})}=\mathrm{m}_{0}-\Delta \mathrm{m}[1-\exp (-\mathrm{kt})]
$$

where $\mathrm{m}_{0}$ is the weight of the sample $(\mathrm{mg}) ; \mathrm{m}_{(\mathrm{t})}$ is the weight of the sample at time $\mathrm{t}$ during the test; and $\Delta \mathrm{m}$ is the weight increase after reaching the adsorption equilibrium. Figure $2 \mathrm{~d}$ shows that the adsorption kinetic constant (k) for $\mathrm{Cu} / \mathrm{HA}$ and $\mathrm{Cu} 1 \mathrm{Zn} 3 /$ HA was 10 20 $\mu \mathrm{g}_{\mathrm{P} \text {-xylene }} \mathrm{s}^{-1}$, which was more than four times higher than that of CA $\left(0 \sim 5 \mu g_{\text {P-xylene }} \mathrm{s}^{-1}\right)$. It clearly indicates that, compared to bulky commercial alumina, the introduction of a hierarchically porous structure largely promotes the mass transportation of organic molecules in the sample.

\subsection{The Property of Bimetallic $\mathrm{Cu}-\mathrm{Zn}$ Supported on Hierarchically Porous $\gamma-\mathrm{Al}_{2} \mathrm{O}_{3}$}

The reduction temperature for $\mathrm{Cu}-\mathrm{Zn} / \mathrm{HA}$ samples was chosen based on temperatureprogrammed reduction results (Figure $3 \mathrm{a}$ ). $\mathrm{A} \mathrm{H}_{2}$ consumption peak was observed at $260{ }^{\circ} \mathrm{C}$ for mono-metal $\mathrm{Cu} / \mathrm{CA}$, while a slightly higher reduction temperature of around $267^{\circ} \mathrm{C}$ was observed for mono-metal $\mathrm{Cu} / \mathrm{HA}$. The higher reduction temperature indicates a stronger interaction between $\mathrm{Cu}$ and hierarchically porous $\mathrm{Al}_{2} \mathrm{O}_{3}$ in $\mathrm{Cu} / \mathrm{HA}$ than that with $\mathrm{Cu} / \mathrm{CA}$. After the addition of $\mathrm{Zn}$, the reduction temperature shifted to $269{ }^{\circ} \mathrm{C}$ for $\mathrm{Cu} 1 \mathrm{Zn} 1 / \mathrm{HA}$. With an increasing $\mathrm{Zn}$ loading in bi-metal $\mathrm{Cu}-\mathrm{Zn} / \mathrm{CA}$ samples, the reduction temperature gradually increased to $292^{\circ} \mathrm{C}$ and $310^{\circ} \mathrm{C}$ for $\mathrm{Cu} 1 \mathrm{Zn} 3 / \mathrm{HA}$ and $\mathrm{Cu} 1 \mathrm{Zn} 5 / \mathrm{HA}$, respectively. It is well known that mono-metal $\mathrm{Zn}$ has no reduction peak at any temperature lower than $550{ }^{\circ} \mathrm{C}$ [20]; the $\mathrm{H}_{2}$ consumption peak is thus mainly due to the reduction of $\mathrm{Cu}^{2+}$. Furthermore, the high reduction temperature in bi-metal $\mathrm{Cu}-\mathrm{Zn} / \mathrm{CA}$ with an increase in the $\mathrm{Zn}$ loading indicates that a strong interaction existed between $\mathrm{Cu}$ and $\mathrm{Zn}$. Finally, a reduction temperature of $350{ }^{\circ} \mathrm{C}$ was thus selected for the activation of all the samples.

After reduction at $350^{\circ} \mathrm{C}$ for $2 \mathrm{~h}$ in $\mathrm{H}_{2}$, the state of the $\mathrm{Cu}$ and $\mathrm{Zn}$ phase was analyzed by X-ray diffraction patterns (Figure $3 b$ ). It shows a broad peak at around $46^{\circ}$ for all the samples, which corresponds to the $\gamma-\mathrm{Al}_{2} \mathrm{O}_{3}$ support (JCPDS: 01-1303). In addition, an additional peak appeared at around $43.3^{\circ}$ in the reduced mono-metal $\mathrm{Cu} / \mathrm{HA}$ sample, and it belongs to the (111) crystallite surface of metallic Cu (JCPDS card: 85-1326). After alloying $\mathrm{Cu}$ with $\mathrm{Zn}$, a peak at $\sim 43.3^{\circ}$, belonging to the (110) of Cu1Zn1 alloy, appeared in all bi-metal $\mathrm{Cu}-\mathrm{Zn} / \mathrm{HA}$ samples. Based on Scherrer's equation, the average particle size was calculated to be around $4 \mathrm{~nm}$ in the $\mathrm{Cu} / \mathrm{HA}$ and $\mathrm{Cu}-\mathrm{Zn} / \mathrm{HA}$ samples. No peaks corresponding to $\mathrm{Zn}$ 's phase were observed in any of the reduced $\mathrm{Cu}-\mathrm{Zn} / \mathrm{HA}$ samples. It was reported that the state of reduced $\mathrm{Zn}$ is difficult to identify by XRD, especially on a support [34]. The reduced $\mathrm{Cu}-\mathrm{Zn} / \mathrm{HA}$ samples were further analyzed by diffuse reflectance UV-vis spectroscopy (Figure 3c). The contribution of the support was firstly removed by using $\mathrm{Al}_{2} \mathrm{O}_{3}$ as the baseline. Two absorption bands, $\lambda_{\max } \sim 270 \mathrm{~nm}$ and $\sim 640 \mathrm{~nm}$, were observed in the reduced mono-metal $\mathrm{Cu} / \mathrm{HA}$ sample. These two bands are the characteristic bands of copper, and they are attributed to the localized surface plasmon resonance of free electrons and the inter-band transitions $[43,44]$. After alloying $\mathrm{Cu}$ with $\mathrm{Zn}$, the characteristic bands 
of metallic $\mathrm{Cu}$, especially $\lambda_{\max }$ in the visible region, showed a blue shift to $630 \mathrm{~nm}, 625 \mathrm{~nm}$ and $600 \mathrm{~nm}$ for Cu1Zn1/HA, Cu1Zn3/HA and Cu1Zn5/HA, respectively. This type of blue shift mainly originated from the electron transfer from $\mathrm{Zn}$ atoms to $\mathrm{Cu}$, very probably due to the formation of $\mathrm{Cu}-\mathrm{Zn}$ alloy (i.e., $\mathrm{Cu} 1 \mathrm{Zn} 1$ alloy), which results in an increase in the density of free electrons in copper after reduction at $350{ }^{\circ} \mathrm{C}[45]$.
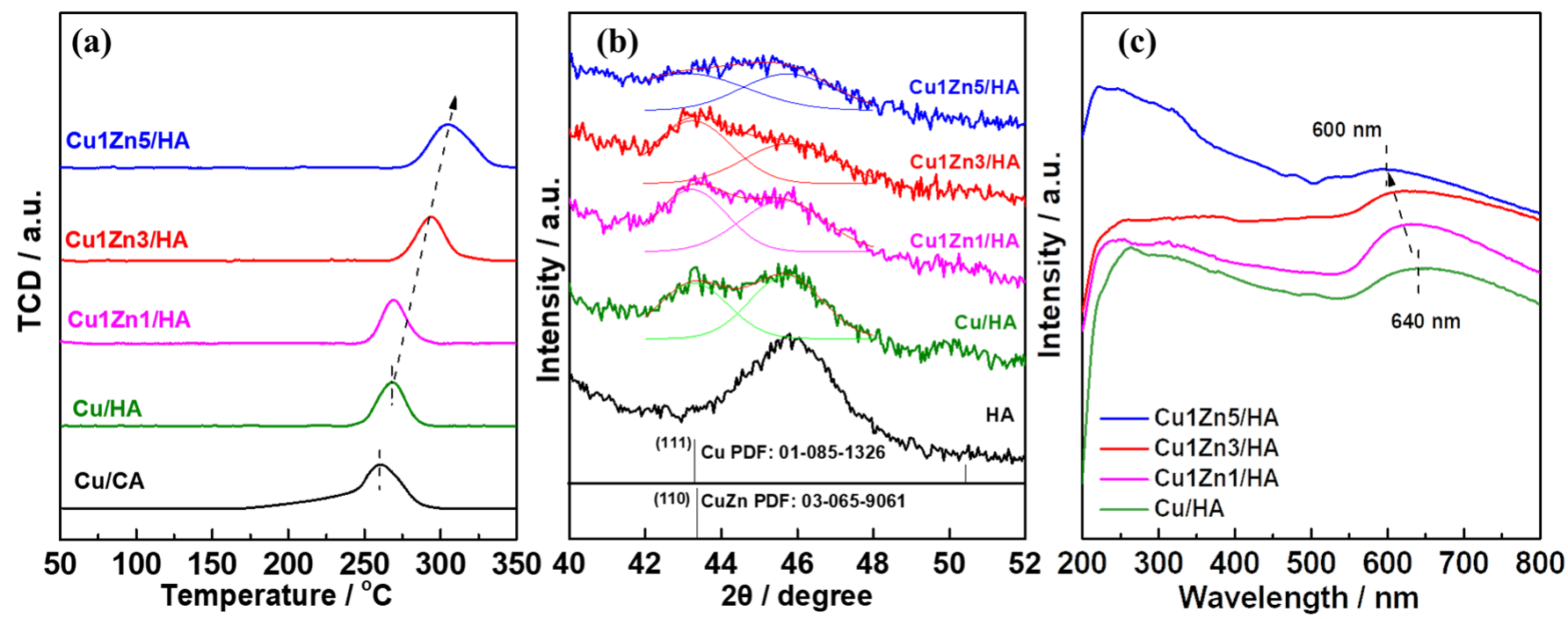

Figure 3. (a) Temperature programmed reduction of $\mathrm{Cu}-\mathrm{Zn} / \mathrm{Al}_{2} \mathrm{O}_{3}$; (b) $\mathrm{XRD}$ of $\mathrm{Cu}-\mathrm{Zn} / \mathrm{Al}_{2} \mathrm{O}_{3}$ after reduction at $350{ }^{\circ} \mathrm{C}$ for $2 \mathrm{~h}$; (c) $\mathrm{UV}$-visible spectra of the calcined-reduced $\mathrm{Cu}-\mathrm{Zn} / \mathrm{Al}_{2} \mathrm{O}_{3}$ samples with $\mathrm{Al}_{2} \mathrm{O}_{3}$ as baseline.

To obtain further information about the composition and the particle size of the supported metallic nanoparticles, STEM-HAADF coupled with EDX was employed on the calcined then reduced mono-metal $\mathrm{Cu} / \mathrm{Al}_{2} \mathrm{O}_{3}$ and bi-metal $\mathrm{Cu}-\mathrm{Zn} / \mathrm{Al}_{2} \mathrm{O}_{3}$ samples (Figure 4). The particle size of the $\mathrm{Cu}$ on the bulky commercial $\mathrm{Al}_{2} \mathrm{O}_{3}$ support was around $15 \pm 2 \mathrm{~nm}$, while it dramatically decreased to around $1.7 \pm 0.5 \mathrm{~nm}$ when the support was hierarchically porous $\mathrm{Al}_{2} \mathrm{O}_{3}$ (Figure S4). The much higher surface area of HA (i.e., $394 \mathrm{~m}^{2} \mathrm{~g}^{-1}$ ), being 130 times that of $\mathrm{CA}\left(3 \mathrm{~m}^{2} \mathrm{~g}^{-1}\right)$, offered a much better $\mathrm{Cu}$ dispersion at a similar $\mathrm{Cu}$ loading. In addition, compared to mono-metal $\mathrm{Cu} / \mathrm{HA}$, the additional $\mathrm{Zn}$ had a limited effect on the metal particle size, with the average particle sizes being $1.8 \pm 0.3,1.2 \pm 0.5$ and $2.2 \pm 0.5$ for Cu1Zn1/HA, Cu1Zn3/HA and Cu1Zn5/HA, respectively (Figure S4). The composition of the metallic particles was analyzed by EDX dotting, e.g., for the Cu1Zn3/HA sample in Figure $4 \mathrm{f}$. Three large particles (with diameters of $4 \sim 5 \mathrm{~nm}$ ) were found by STEM-HAADF. The atomic ratios between $\mathrm{Cu}$ and $\mathrm{Zn}$ in these particles were around 1:1. This confirms that the large metallic particles (4-5 nm) in the bi-metal $\mathrm{Cu}-\mathrm{Zn} / \mathrm{HA}$ were mainly $\mathrm{Cu}-\mathrm{Zn}$ alloy; i.e., $\mathrm{Cu}-\mathrm{Zn}$ with an atomic ratio of 1:1 was formed in the $\mathrm{Cu} 1 \mathrm{Zn} 3 / \mathrm{HA}$ sample. The excess of $\mathrm{Zn}$ was also identified by STEM-HAADF in Figure S5. Therefore, the observed XRD peak at $43^{\circ}$ for bimetal $\mathrm{Cu}-\mathrm{Zn} / \mathrm{HA}$ was supposed to be the (110) crystallite surface of Cu1Zn1 alloy (JCPDS card: 65-9061) (Figure 3b). The small particles $(<2 \mathrm{~nm})$ in the $\mathrm{Cu}-\mathrm{Zn} / \mathrm{HA}$ samples were further analyzed by high resolution transmission electron microscopy with a double spherical aberration correction, e.g., for Cu1Zn3/HA sample in Figure $4 \mathrm{~g}-\mathrm{i}$. With increasing magnification, sub-nanoclusters and automatically dispersed metallic atoms were mainly observed. According to the EDX mapping in Figure $4 \mathrm{~h}$, the metallic particles $(\sim 2 \mathrm{~nm})$ contained metallic $\mathrm{Cu}$, with small amounts of $\mathrm{Zn}$. Automatically dispersed metallic atoms corresponded to $\mathrm{Cu}^{0}$. As a result, the TEM-EDX indicated that the bimetal $\mathrm{Cu}-\mathrm{Zn} / \mathrm{HA}$ samples mainly had $\mathrm{Cu}-\mathrm{Zn}$ nanoalloy clusters, with plenty of atomically dispersed $\mathrm{Cu}$. 


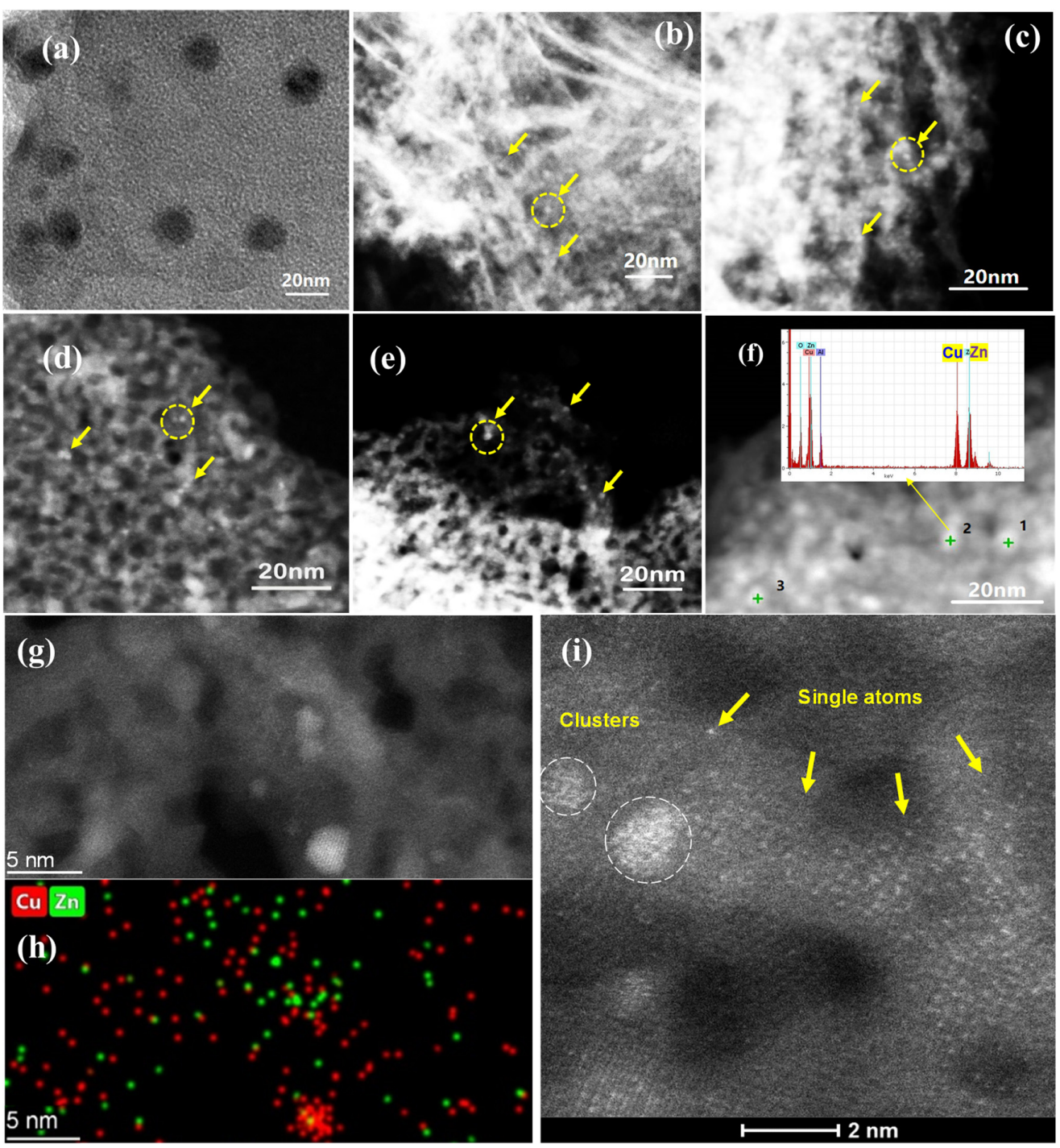

Figure 4. STEM of reduced Cu/CA (a), STEM-HAADF of reduced Cu/HA (b), Cu1Zn1/HA (c), Cu1Zn3/HA (d,g,i) and Cu1Zn5/HA (e); the EDX dotting (f) and mapping (h) of a Cu1Zn3/HA sample.

\subsection{Catalytic Performance for Selective Butadiene Hydrogenation in an Excess of Propene}

After in situ reduction at $350{ }^{\circ} \mathrm{C}$ for $2 \mathrm{~h}$ under $\mathrm{H}_{2}$, the catalytic performance, including activity, alkene selectivity and stability, of the supported $\mathrm{Cu}-\mathrm{Zn}$ samples for the selective hydrogenation of butadiene was evaluated (Figure 5) on $200 \mathrm{mg}$ of each catalyst (sieve fraction, $125-200 \mu \mathrm{m})$, with similar Cu content ( $2.5 \mathrm{wt} \%)$.

In Figure $5 \mathrm{a}$, it can be seen that mono-metallic $\mathrm{Cu}$ supported on the bulky commercial $\mathrm{Al}_{2} \mathrm{O}_{3}$ catalyst $(\mathrm{Cu} / \mathrm{CA})$ had a maximum butadiene conversion temperature $\left(\mathrm{T}_{\max }\right)$ of around $200{ }^{\circ} \mathrm{C}$, while the introduction of the porous hierarchy into $\mathrm{Al}_{2} \mathrm{O}_{3}$ brought a decrease in the $\mathrm{T}_{\max }$ to $\sim 175{ }^{\circ} \mathrm{C}$ for the $\mathrm{Cu} / \mathrm{HA}$. The enhanced activity in the $\mathrm{Cu} / \mathrm{HA}$ resulted from both the smaller size of the supported $\mathrm{Cu}$ nanoparticles and the promoted mass transportation owing to the hierarchically porous structure in the HA support. However, in comparison with the previous study of $\mathrm{Cu} / \mathrm{TiO}_{2}\left(\mathrm{~T}_{\max } \sim 75^{\circ} \mathrm{C}\right)$ [34], the high $\mathrm{T}_{\max }$ (i.e., low activity) of mono-metallic $\mathrm{Cu}$ supported on alumina might have been be caused by the effect of different metal oxide supports owing to the metal-support interaction. Furthermore, the addition of zinc to the mono-metallic $\mathrm{Cu} / \mathrm{HA}$ resulted in an increase in $\mathrm{T}_{\max }$. With the increase in the $\mathrm{Zn}$ loading, the $\mathrm{T}_{\max }$ increased to 200,220 and $230^{\circ} \mathrm{C}$ for Cu1Zn1/HA, Cu1Zn3/HA and Cu1Zn5/HA, respectively. The lower catalytic activity (i.e., higher $\mathrm{T}_{\max }$ ) in the bi-metallic $\mathrm{Cu}-\mathrm{Zn} / \mathrm{HA}$ catalyst was caused by the less exposed $\mathrm{Cu}$ active sites in 
$\mathrm{CuZn}$ alloy than those in the mono-metallic $\mathrm{Cu}$, as $\mathrm{Zn}$ had no activity to the catalytic reaction. A similar observation on supported bi-metallic catalysts (i.e., $\mathrm{Au}-\mathrm{Zn}$ [46], Pd$\mathrm{Zn}$ [47], Cu-Zn [34] etc.) was previously reported. This result is also in good agreement with the theoretical prediction made by Nørskov [13] that $\mathrm{Cu}-\mathrm{Zn}$ alloy has a lower activity than metallic $\mathrm{Cu}$.

The catalytic selectivity of $\mathrm{Cu}-\mathrm{Zn}$ catalysts is presented in Figure 5b. To simulate the real situation in industry (e.g., a butadiene impurity in an excess of butenes), $3000 \mathrm{ppm}$ of butadiene in $30 \%$ of propene with helium as the balance gas was used as the raw materials in this study; thus, the catalytic selectivity could be expressed as both selectivity to butenes and alkanes (butane and propane) formation. In Figure $5 b$, it can be seen that the selectivity to butenes slightly decreased with the increase in the butadiene conversion; however, all Cu-based catalysts showed a high catalytic selectivity to butenes (i.e., $>90 \%$ ), with less than $10 \%$ alkane (butane and propene) formation. The advantage of the porous hierarchy can be clearly observed by comparing the alkene selectivity between $\mathrm{Cu} / \mathrm{CA}$ and $\mathrm{Cu} / \mathrm{HA}$. Specifically, $\mathrm{Cu}$ supported on hierarchically porous $\mathrm{Al}_{2} \mathrm{O}_{3}$ showed a higher selectivity to alkenes than did commercial bulky $\mathrm{Al}_{2} \mathrm{O}_{3}$. With the butadiene conversion increased from 20 to $100 \%$, the butene selectivity decreased from $100 \%$ to $97 \%$ and from $98.5 \%$ to $\sim 90 \%$ for $\mathrm{Cu} / \mathrm{HA}$ and $\mathrm{Cu} / \mathrm{CA}$, respectively. The superior alkene selectivity of $\mathrm{Cu} / \mathrm{HA}$ was mainly due to the rapid guest molecule diffusion in $\mathrm{Cu} / \mathrm{HA}$ (Figure 2d) shortening the residence time of the reactants over the copper's active site, avoiding the over-hydrogenation of butenes during the catalytic reaction [48]. In addition, the promotional effect of alloying $\mathrm{Cu}$ with $\mathrm{Zn}$ was checked by analyzing the alkene selectivity of $\mathrm{Cu}-\mathrm{Zn} / \mathrm{HA}$ catalysts. The alkene selectivity of bi-metallic $\mathrm{Cu}-\mathrm{Zn} / \mathrm{HA}$ stayed above $97 \%$ at $\sim 100 \%$ butadiene conversion (e.g., $\sim 99 \%$ alkene selectivity for $\mathrm{Cu} 1 \mathrm{Zn} 3 / \mathrm{HA}$ ) as the modified electronic structure of the copper site by the formation of $\mathrm{Cu}-\mathrm{Zn}$ alloy (Figure 3c). Even though the previous $\mathrm{Cu}-\mathrm{Zn} / \mathrm{TiO}_{2}$ study [34] showed a decrease in the butene selectivity at $100 \%$ butadiene conversion after alloying $\mathrm{Zn}$ with $\mathrm{Cu}$, it attributed this type of decrease in the alkene selectivity to a gradual deactivation of the mono-metallic copper during the slow heating ramp. In this study, the developed $\mathrm{Cu}-\mathrm{Zn} / \mathrm{HA}$ catalysts were stable enough (as discussed later); it is able to show a clear advantage of $\mathrm{Zn}$ for enhancing the alkene selectivity of $\mathrm{Cu}$. Moreover, compared with $\mathrm{Cu} / \mathrm{CA}$, the $\mathrm{Cu}-\mathrm{Zn} / \mathrm{HA}$ catalysts showed a much higher selectivity to butenes, especially at a high butadiene conversion. For example, the Cu1Zn3/HA samples had an alkane (butane and propane) formation of $\sim 2 \%$, which was four times lower than that of $\mathrm{Cu} / \mathrm{CA}$ sample, at a butadiene conversion close to $100 \%$. This type of highly improved selectivity was indeed due to the synergistic effect of the rapid mass transportation and modified property of active site.

Butadiene conversion as a function of the time on stream was evaluated on $\mathrm{Cu}-$ $\mathrm{Zn} / \mathrm{Al}_{2} \mathrm{O}_{3}$ samples and presented in Figure $5 \mathrm{c}$, with a similar initial butadiene conversion of $\sim 60 \%$. The reference catalyst (i.e., $\mathrm{Cu} / \mathrm{CA}$ ) had a very low catalytic stability and its butadiene conversion rapidly decreased from $60 \%$ to below $20 \%$ in the first $2 \mathrm{~h}$ of isothermal reaction. However, the butadiene conversion remained relatively stable for the monometallic $\mathrm{Cu}$ supported on $\mathrm{HA}$, which showed a slight decrease to $35 \%$ after $70 \mathrm{~h}$ of time on stream. This type of enhancement in the catalytic stability in the $\mathrm{Cu} / \mathrm{HA}$ catalyst could be mainly due to the introduced hierarchically porous structure, which highly accelerated the mass transportation and improved the copper's dispersion, leading to an increase in the reactant transfer on the surface of the Cu's catalytically active site. Previous studies proved that the formation of oligomers (i.e., C8 to C22) by the oligomerization of neighboring intermediate carbenes is the main reason for the deactivation of supported metal [27]. Moreover, Louis et al. [49] verified that the decomposition of oligomers mainly happens at temperatures lower than $450^{\circ} \mathrm{C}$ by thermo-gravimetry coupled with mass spectra analysis. Here, the oligomers formation on $\mathrm{Cu}$ catalysts after a stability test was evaluated by thermogravimetry analysis in air (Figure S6). The weight loss of the $\mathrm{Cu} / \mathrm{CA}$ and $\mathrm{Cu} / \mathrm{HA}$ was $5.4 \mathrm{wt} \%$ and $4 \mathrm{wt} \%$, respectively. It indicates that the rapid reactants transportation in the porous hierarchy brought a low oligomer formation, hence a slower deactivation rate. 
The addition of $\mathrm{Zn}$ to $\mathrm{Cu}$ highly improved the catalytic stability of $\mathrm{Cu}$ in the selective hydrogenation reaction. In the first $70 \mathrm{~h}$ of reaction, the butadiene conversion decreased from $60 \%$ to $45 \%$ and $50 \%$ for Cu1Zn1/HA and Cu1Zn3/HA, respectively. However, it decreased from $60 \%$ to $\sim 25 \%$ for the $\mathrm{Cu} 1 \mathrm{Zn} 5 / \mathrm{HA}$ sample. These are much more stable results than the previous $\mathrm{Cu}-\mathrm{Zn} / \mathrm{TiO}_{2}$ catalysts $(\mathrm{Cu}: \mathrm{Zn}<1: 1)$ [34], which had above $20 \%$ of deactivation in $20 \mathrm{~h}$ of time on stream. Moreover, this work also proposed a suitable $\mathrm{Zn}$ loading range $(\mathrm{Cu}: \mathrm{Zn} \approx 1: 3)$ for bi-metallic $\mathrm{Cu}-\mathrm{Zn}$ catalysts for the selective hydrogenation reaction. Based on the ICP, XRD and EDX characterization, two types of zinc existed in the bi-metallic $\mathrm{Cu}-\mathrm{Zn}$ catalysts. One was that alloyed with $\mathrm{Cu}$ and another one was highly dispersed on the $\mathrm{Al}_{2} \mathrm{O}_{3}$ support, and the distribution of $\mathrm{Zn}$ was imaged by EDX mapping in Figure S5. The main function of the $\mathrm{Zn}$ that alloyed with $\mathrm{Cu}$ was its modification of the adsorption mode or strength of the reactants and/or products of the reaction as it was reported in a previous bi-metallic $\mathrm{Cu}-\mathrm{Zn}$ study [34], resulting in a decrease of green oil formation (Figure S6), e.g., only a $2.5 \mathrm{wt} \%$ weight loss for Cu1Zn3/HA. The positive role of $\mathrm{Zn}$ in $\mathrm{Ni}-\mathrm{Zn}$ alloy was recently explored in the selective hydrogenation of acetylene, and it was found that alloying Zn with Ni could decrease the resultant coverage of acetylene, and weaken the carbon chain growth reaction (oligomerization reaction) [27]. This was attributed to changes in the electronic properties of $\mathrm{Ni}$ on the surface by alloying with $\mathrm{Zn} \mathrm{[13].} \mathrm{The} \mathrm{same} \mathrm{effect} \mathrm{might} \mathrm{also} \mathrm{apply} \mathrm{to} \mathrm{the} \mathrm{case} \mathrm{of} \mathrm{the} \mathrm{Cu}-\mathrm{Zn}$ system, as a recent study based on DFT calculations found the existence of a charge transfer between the $\mathrm{Cu}$ and $\mathrm{Zn}$ atoms in $\mathrm{Cu}_{0.7} \mathrm{Zn}_{0.3}$ alloy [50]. In addition to the modification of the electronic properties of $\mathrm{Cu}$, alloying with $\mathrm{Zn}$ also brought a geometric effect. $\mathrm{Zn}$ had no catalytic activity in butadiene hydrogenation; alloying $\mathrm{Zn}$ with copper was supposed to dilute the Cu catalytic active site, and increase the average distance between $\mathrm{Cu}$ active sites on the surface of nano metallic particles. As it was presented in Figure S7, the crystal structure of metallic $\mathrm{Cu}$ and $\mathrm{Cu} 1 \mathrm{Zn} 1$ shows that, as for mono-metallic $\mathrm{Cu}$, the distance between neighboring Cu was around $2.5562 \AA$, which was shorter than the length of the butadiene molecular size (3.556 ̊). After alloying with $\mathrm{Zn}$, the distance between two copper atoms enlarged to $3.959 \AA$. Since the oligomerization reaction on a catalytic surface requires a sufficiently short distance between the co-adsorbed hydrocarbon molecules [51], the isolation of $\mathrm{Cu}$ by alloying with $\mathrm{Zn}$ could also avoid undesired side reactions for green oil formation. A A similar geometric effect has also been observed in the bi-metallic Ni-Cu system; the isolated $\mathrm{Ni}-\mathrm{Cu}$ sites showed larger coupling barriers to $\mathrm{C}-\mathrm{C}$ bond formation than pure $\mathrm{Ni}$ or $\mathrm{Cu}$ sites owing to the alloy structure offering a high resistance to the formation of oligomers during propyne hydrogenation [52]. The fraction of zinc that is un-alloyed with copper on an $\mathrm{Al}_{2} \mathrm{O}_{3}$ surface may modify the surficial acidic property of $\mathrm{Al}_{2} \mathrm{O}_{3}$ [34], as the acidic sites on the support surface could adsorb hydrocarbons and provoke not only isomerisation but also transformation into coke or $\mathrm{C}_{2}-\mathrm{C}_{6}$ hydrocarbons from cracking and disproportionation reactions [5,53].

Once both the hierarchically porous structure and $\mathrm{Cu}$ alloyed with $\mathrm{Zn}$ were simultaneously introduced into $\mathrm{Cu} / \mathrm{Al}_{2} \mathrm{O}_{3}$, a great enhancement in the catalytic stability can be also observed in Figure 5c. More specifically, to make a fair comparison, the time taken to reach a $10 \%$ loss of the butadiene conversion was selected from Figure $5 \mathrm{c}$ and summarized in Figure 6a. $\mathrm{Cu} / \mathrm{CA}$ showed a $10 \%$ butadiene conversion loss within $0.25 \mathrm{~h}$, while that time was $2 \mathrm{~h}, 5 \mathrm{~h}, 40 \mathrm{~h}$ and $10 \mathrm{~h}$ for $\mathrm{Cu} / \mathrm{HA}, \mathrm{Cu} 1 \mathrm{Zn} 1 / \mathrm{HA}, \mathrm{Cu} 1 \mathrm{Zn} 3 / \mathrm{HA}$ and Cu1Zn5/HA, respectively. This indicates that $\mathrm{Cu} 1 \mathrm{Zn} 3 / \mathrm{HA}$ had a catalytic stability 20 times higher than that of $\mathrm{Cu} / \mathrm{HA}$, and 160 times higher than that of $\mathrm{Cu} / \mathrm{CA}$. As a result, the catalytic synergism between a porous hierarchy and alloying could offer a high-efficiency mass transportation and highly dispersed catalytically active site that results in a long-term catalytic reaction (Figure $6 \mathrm{~b}$ ). 

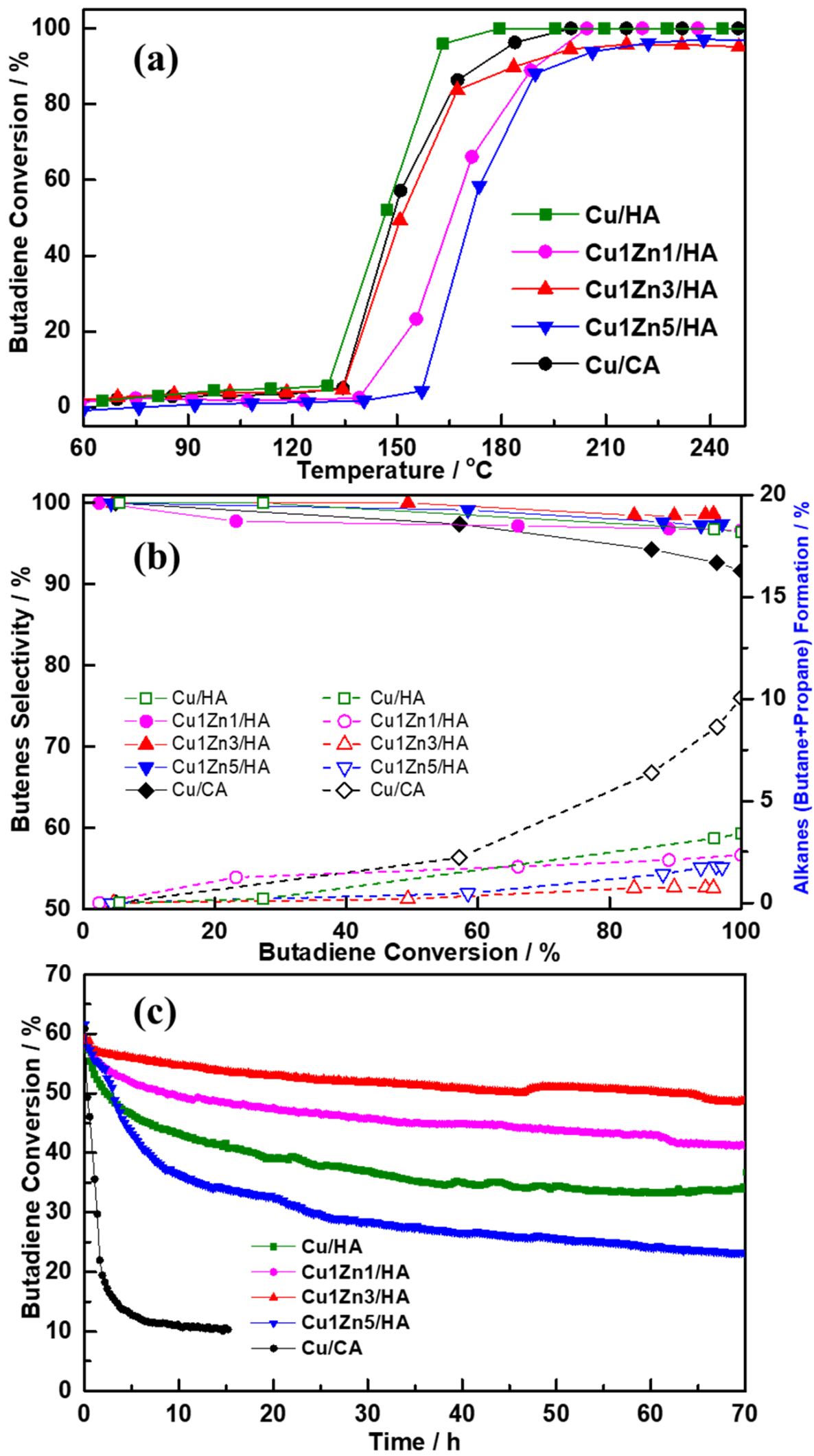

Figure 5. Evolution of the butadiene conversion as a function of reaction temperature (a); the selectivity to butenes (1-butene + cis-2-butene + trans-2-butene) and alkane formation as a function of butadiene conversion (b); butadiene conversion as a function of time on stream (c) for $\mathrm{Cu}-\mathrm{Zn} / \mathrm{Al}_{2} \mathrm{O}_{3}$ catalysts (i.e., $150{ }^{\circ} \mathrm{C}$ for $\mathrm{Cu} / \mathrm{CA}$ and $\mathrm{Cu} / \mathrm{HA} ; 175^{\circ} \mathrm{C}$ for $\mathrm{Cu} 1 \mathrm{Zn} 1 / \mathrm{CA}$ and $\mathrm{Cu} 1 \mathrm{Zn} 5 / \mathrm{HA}$; and $160{ }^{\circ} \mathrm{C}$ for Cu1Zn1/CA). 
(a)

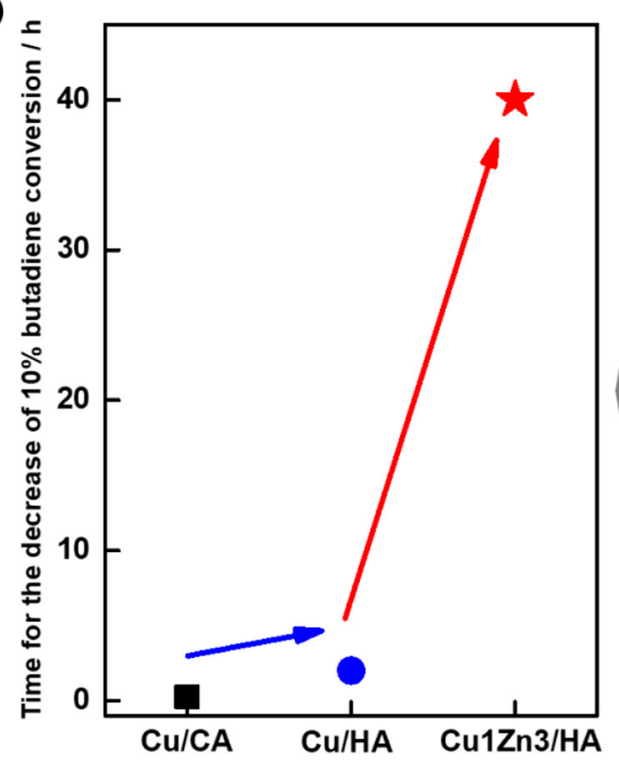

(b)

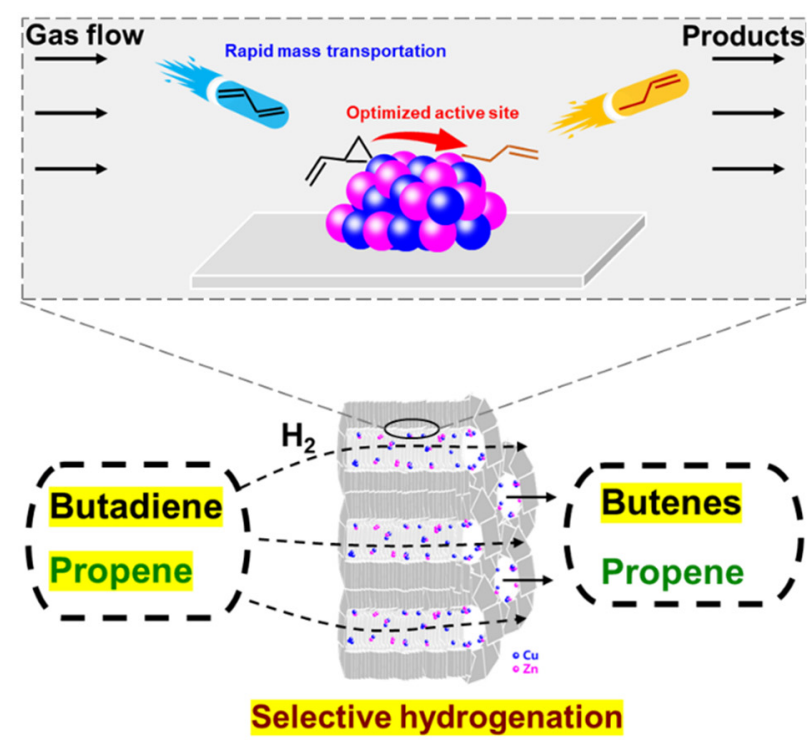

Figure 6. Evolution of the time needed to reach a $10 \%$ butadiene conversion decrease with different structures and compositions of samples (a) and a scheme of the synergistic effect of porous hierarchy and alloying in a catalytic reaction (b).

\section{Experiment}

3.1. Sample Preparation

\subsubsection{Materials and Chemicals}

The chemicals used were acetonitrile (Aladdin, ACS, 99.4\%, Shanghai, China), aluminum sec-butoxide (Aladdin, 97\%, Shanghai, China), distilled water, $\mathrm{Cu}\left(\mathrm{NO}_{3}\right)_{2} \cdot 3 \mathrm{H}_{2} \mathrm{O}$ (Sinopharm, AR, Shanghai, China), $\mathrm{Zn}\left(\mathrm{NO}_{3}\right)_{2} \cdot 6 \mathrm{H}_{2} \mathrm{O}$ (Sinopharm, AR, Shanghai, China) and urea (Sinopharm, AR, Shanghai, China). All were used as purchased during the whole sample synthesis procedure.

\subsubsection{Preparation of Hierarchically Porous Alumina}

Hierarchically porous alumina (HA) was synthesized by a one-step method in the absence of any templates. In a typical preparation process, $3 \mathrm{~mL}$ of distilled water was dropped into $17 \mathrm{~mL}$ of acetonitrile under stirring at room temperature for $30 \mathrm{~min}$. A mass of $2 \mathrm{~g}$ of aluminum sec-butoxide (TBOA) was dropped into the above solvent without stirring, and the suspension was statically kept at room temperature for $30 \mathrm{~min}$. The precipitate was collected by filtration and dried at $60^{\circ} \mathrm{C}$ for 1 day. Calcination at $550{ }^{\circ} \mathrm{C}$ under air for $3 \mathrm{~h}$ with a ramp rate of $2{ }^{\circ} \mathrm{C} \mathrm{min}^{-1}$ was performed, leading to the formation of HA support.

\subsubsection{Preparation of $\mathrm{Cu}-\mathrm{Zn} / \mathrm{HA}$ Catalysts}

HA-supported mono-metal $\mathrm{Cu}$ and bi-metal $\mathrm{Cu}-\mathrm{Zn}$ catalysts were prepared by deposition-precipitation with urea (DPu) as previously described [54,55]. Specifically, $2 \mathrm{~g}$ of HA support was dispersed in $200 \mathrm{~mL}$ of distilled water in a double-walled reactor $\left(\mathrm{m}_{\mathrm{HA}} / \mathrm{V}_{\text {water }}=1: 100\right)$ at room temperature. The pre-defined weight of $\mathrm{Cu}\left(\mathrm{NO}_{3}\right)_{2} \cdot 3 \mathrm{H}_{2} \mathrm{O}$ and $\mathrm{Zn}\left(\mathrm{NO}_{3}\right)_{2} \cdot 6 \mathrm{H}_{2} \mathrm{O}$ were added into the suspension to achieve a desired nominal copper loading with various $\mathrm{Cu}: \mathrm{Zn}$ atomic ratios of 1:0, 1:1, 1:3 and 1:5. Urea was dissolved in the above suspension to achieve a urea-to-metal molar ratio of ca. 100. The mixture was kept at $80^{\circ} \mathrm{C}$ for $20 \mathrm{~h}$ under a mild stirring. The solid sample was collected by centrifugation and subsequently washed with distilled water and centrifuged three times. Finally, the solids were dried at $60^{\circ} \mathrm{C}$ overnight and calcined in a muffle furnace at $400{ }^{\circ} \mathrm{C}$ for $2 \mathrm{~h}$ with a heating rate of $5^{\circ} \mathrm{C} \mathrm{min}^{-1}$ (as prepared).

For comparison, bulky commercial $\mathrm{Al}_{2} \mathrm{O}_{3}$ (CA, Aladdin, CAS: 1344-28-1, size of $200 \mathrm{~nm}$ ) was also used as a support. Note that the CA reference must have a large particle size, 
which could lead to porous structure formation during sample post-treatment (e.g., drying, sieving etc.). CA-supported mono-metallic $\mathrm{Cu}$ was synthesized through the same $\mathrm{DPu}$ procedure described above.

In this study, the nominal $\mathrm{Cu}$ loading in all samples was kept at $2.5 \mathrm{wt} \%$. Specifically, $\mathrm{Cu} / \mathrm{HA}$ and $\mathrm{Cu} / \mathrm{CA}$ corresponded to mono-metal $\mathrm{Cu}$ deposited on HA and $\mathrm{CA}$, respectively. While, $\mathrm{Cu} 1 \mathrm{Zn} 1 / \mathrm{HA}, \mathrm{Cu} 1 \mathrm{Zn} 3 / \mathrm{HA}$ and $\mathrm{Cu} 1 \mathrm{Zn} 5 / \mathrm{HA}$ corresponded to bimetal $\mathrm{Cu}-\mathrm{Zn}$ deposited on HA support, with nominal $\mathrm{Cu} Z \mathrm{Zn}$ atomic ratios of 1:1, 1:3 and $1: 5$, respectively.

\subsection{Catalysts Characterization}

Metal loadings in the as-prepared samples were analyzed for their contents and relative ratios of $\mathrm{Cu}$ to $\mathrm{Zn}$ in different catalysts by inductively coupled plasma spectrometry (ICP; Lehman-Merbu, Prodigy 7). The wavelength range was 165 to $1100 \mathrm{~nm}$.

The reduction behavior of the supported metals was checked by temperature programmed reduction under $5 \% \mathrm{H}_{2} / \mathrm{Ar}$ atmosphere $\left(\mathrm{H}_{2}\right.$-TPR; Micromeritics, AutoChem1 II 2920) using $100 \mathrm{mg}$ of as-prepared samples. An Ar purge $\left(25 \mathrm{~mL} \mathrm{~min}^{-1}\right)$ was performed for $30 \mathrm{~min}$ to remove the air in the reactor at room temperature (RT) before increasing the temperature from room temperature to $550^{\circ} \mathrm{C}$ at a linear rate $\left(7.5^{\circ} \mathrm{C} \mathrm{min}-1\right)$ in a $5 \% \mathrm{H}_{2} / \mathrm{Ar}$ gas mixture flow $\left(25 \mathrm{~mL} \mathrm{~min}^{-1}\right)$.

The crystalline structures of samples were determined by powder X-ray diffraction (XRD; Bruker D8 Advance, $\mathrm{Cu} \mathrm{K} \alpha$ radiation; $40 \mathrm{kV}$ and $30 \mathrm{~mA}$ ) with a scan rate of $0.5^{\circ} \mathrm{min}^{-1}$. The 2-theta angle ranged from $5^{\circ}$ to $90^{\circ}$.

Surface morphology and metallic particle size were analyzed by scanning electron microscope (SEM; Hitachi, S-4800, Tokyo, Japan) equipped with energy dispersive X-ray spectrometer (EDX), and STEM-HAADF was performed on the machine Talos F200S (Thermo Fisher Scientific, Waltham, MA, USA). Moreover, single atomic $\mathrm{Cu}$ dispersion was analyzed by spherical-aberration-corrected transmission electron microscope (TEM; Tian G260-300, 200 kV, Thermo Fisher Scientific, Waltham, MA, USA). Statistical analysis of the nanoparticle size distributions in the reduced samples was obtained by counting more than 200 particles using the software Image J. The average particle diameter was deduced from the equation $d_{m}=\sum n_{i} d_{i} / \sum n_{i}$, where $n_{i}$ is the number of the particles of diameter $d_{i}$.

Nitrogen adsorption-desorption isotherms were collected at $77 \mathrm{~K}$ with an ASAP3020(Micromeritics, Norcross, GA, USA) surface area analyzer manufactured by Micromeritics. The surface area was calculated from the adsorption branch using the BrunauerEmmett-Teller (BET) method, and the pore size distribution was obtained based on the desorption branch with the Barrett-Joyner-Halenda (BJH) approach.

The mass transportation behavior in the hierarchically porous structure was evaluated by intelligent gravimetric analyzer (IGA, HIDEN ISOCHEMA Ltd., IGA100B, Hiden Isochema, Warrington, $\mathrm{UK}$ ) using p-xylene as the probe molecular at $50{ }^{\circ} \mathrm{C}$ under ambient pressure. The weight of each sample was recorded every $0.12 \mathrm{~s}$ during $\mathrm{p}$-xylene diffusion and adsorption.

The thermo-gravimetry analysis (TGA) was carried out on a thermogravimetric analyzer (Setaram Labsys Evo TGA-50, Setaram, Caluire-et-Cuire, France) from 150 to $450{ }^{\circ} \mathrm{C}$ in air with heating rate of $7.5^{\circ} \mathrm{C} \mathrm{min}-1$.

\subsection{Butadiene Selective Hydrogenation Reaction}

The selective hydrogenation reaction was performed in a plug flow microreactor (inner diameter, $4 \mathrm{~mm}$ ) either for the temperature programmed reaction (TP-reaction) or isothermal reaction under atmospheric pressure. To simulate the real situation in industry, which contains small amount of alkadiene impurities in alkenes, butadiene $(0.3 \%)$ with an excess of propene (30\%) was employed as the unsaturated hydrocarbons mixture in this study. The use of propene instead of butene made the butadiene hydrogenation products (i.e., butenes and butane) easily identifiable by gas chromatography; moreover, propene and butenes have a similar reactivity on the surface of metallic $\mathrm{Cu}$ [54], resulting 
in no side effect on the catalytic reaction from the introduction of propene. Specifically, $200 \mathrm{mg}$ of ex situ calcined catalyst (sieve fraction, 125-200 $\mu \mathrm{m}$ ) was activated in situ under pure $\mathrm{H}_{2}$ (at $50 \mathrm{~mL} \mathrm{~min}{ }^{-1}$ ) from RT to $350{ }^{\circ} \mathrm{C}\left(\right.$ at $2{ }^{\circ} \mathrm{C} \mathrm{min}{ }^{-1}$ ) and kept for $2 \mathrm{~h}$ at final temperature. After the reactor cooled down to room temperature under $\mathrm{H}_{2}$, a mixture consisting of $\sim 0.3 \%$ butadiene, $20 \%$ hydrogen and $30 \%$ propene in He carrier was introduced with a total flow rate of $100 \mathrm{~mL} \mathrm{~min}^{-1}$. In the case of the temperature programmed reaction, the catalytic reaction was carried out from $30{ }^{\circ} \mathrm{C}$ to $300{ }^{\circ} \mathrm{C}$ with a heating rate of $1{ }^{\circ} \mathrm{C} \mathrm{min}{ }^{-1}$. The concentration of reactants and target products was evaluated on-line by gas chromatography (GC2030Smart, FID detector, Tetvoc, Wuhan, China) every $16 \mathrm{~min}$, and thus every $16^{\circ} \mathrm{C}$. In the case of the isothermal reaction, the reaction was carried out directly after cooling down the oven to the testing temperature. The catalytic performance was recorded and studied as a function of time on stream for $70 \mathrm{~h}$.

\section{Conclusions}

In summary, a highly enhanced catalytic stability of supported copper was achieved by the synthesis of hierarchically porous- $\mathrm{Al}_{2} \mathrm{O}_{3}$-supported bi-metallic $\mathrm{Cu}-\mathrm{Zn}$ catalysts. The hierarchically porous $\mathrm{Al}_{2} \mathrm{O}_{3}$, which was synthesized by a "one drop" self-formation method, had a macro-mesoporous structure with pore diameters $1 \mu \mathrm{m}$ and $3.5 \mathrm{~nm}$, respectively. After calcination then reduction at $350^{\circ} \mathrm{C}$ for $2 \mathrm{~h}, \mathrm{Cu}-\mathrm{Zn}$ nanoalloys $(\sim 4 \mathrm{~nm})$, bi-metallic $\mathrm{Cu}$ $\mathrm{Zn}$ clusters $(<2 \mathrm{~nm})$ and atomically dispersed copper were found in bi-metallic $\mathrm{Cu}-\mathrm{Zn} / \mathrm{HA}$ catalysts. The catalytic performance was evaluated by the selective hydrogenation of butadiene in an excess of propene, and it was found that the hierarchically porous structure largely improved the catalytic stability; i.e., the hierarchically porous- $\mathrm{Al}_{2} \mathrm{O}_{3}$-supported $\mathrm{Cu}$ catalyst had a much higher stability (with a $\sim 25 \%$ decrease in conversion after $70 \mathrm{~h}$ of reaction) than bulk- $\mathrm{Al}_{2} \mathrm{O}_{3}$-supported $\mathrm{Cu}$ (with a $\sim 50 \%$ decrease in conversion after $10 \mathrm{~h}$ of reaction), and with a similar catalytic activity and selectivity. Alloying $\mathrm{Cu}$ with $\mathrm{Zn}$ slightly decreased the catalytic activity of $\mathrm{Cu}$, but offered a high catalytic selectivity and stability. Moreover, the synergistic effect between the porous hierarchy and alloying could be clearly observed in the hierarchically porous- $\mathrm{Al}_{2} \mathrm{O}_{3}$-supported bi-metallic $\mathrm{Cu}-\mathrm{Zn}$ catalysts. Specifically, i.e., Cu1Zn3/HA (e.g., Cu1Zn1 alloy) had a catalytic stability 20 times higher than that of $\mathrm{Cu} / \mathrm{HA}$ and 160 times higher than that of $\mathrm{Cu} / \mathrm{CA}$. This study also reveals that the introduction of both a porous hierarchy structure and catalytic promotor by alloying could be an efficient way to improve the catalytic performance of other catalysts.

Supplementary Materials: The following supporting information can be downloaded at: https:/ / www.mdpi.com/article/10.3390/catal12010012/s1, Figure S1: XRD of as-prepared and calcined hierarchically porous alumina; Figure S2: SEM of HA (a), Cu/HA(b), Cu1Zn1/HA(c), Cu1Zn3/HA(d), $\mathrm{Cu} 1 \mathrm{Zn} 5 / \mathrm{HA}(\mathrm{e})$ and $\mathrm{Cu}$ /commercial bulky alumina(f); Figure S3: SEM-EDS of Cu/HA, Cu1Zn1/HA, Cu1Zn3/HA and Cu1Zn5/HA; Figure S4: Particle size distribution. (a) Cu/CA; (b) Cu/HA; (c) $\mathrm{Cu} 1 \mathrm{Zn} 1 / \mathrm{HA}$; (d)Cu1Zn3/HA; (e) Cu1Zn5/HA after calcination at $400{ }^{\circ} \mathrm{C}$ for $2 \mathrm{~h}$ then reduction at $350{ }^{\circ} \mathrm{C}$ for $2 \mathrm{~h}$; Figure S5: STEM-HAADF coupled with EDS on the reduced Cu1Zn3/HA; Figure S6: TG analysis of $\mathrm{Cu} / \mathrm{CA}$ and $\mathrm{Cu}-\mathrm{Zn} / \mathrm{HA}$ samples after stability test; Figure S7: The (111) and (110) crystal surface of metallic Cu (JCPDS:85-1326) and Cu-Zn alloy (JCPDS:65-9061).

Author Contributions: Conceptualization, B.S. and Z.W.; methodology, S.X., formal analysis, S.L., data interpretation, H.Y. and S.J., STEM-HAADF analysis, Z.H., Project administration, Z.W.; writingreview and editing, Z.W., B.S. and L.C.; funding acquisition, Z.W., B.S. and L.C. All authors have read and agreed to the published version of the manuscript.

Funding: This research was funded by the National 111 project of 2020 (B0002), Innovative Research Team (IRT_15R52) of the Chinese Ministry of Education, the National Natural Science Foundation of China (NSFC-21902122), the Postdoctoral Science Foundation of China (grant 2019M652723), National Key R\&D Program of China (grant 2021YFE0115800), the Foshan Xianhu Laboratory of the Advanced Energy Science and Technology Guangdong Laboratory (XHD2020-002) and the Joint Funds of the National Natural Science Foundation of China (grant U20A20122). 
Acknowledgments: Zhao Wang thanks Catherine LOUIS, Laurent DELANNOY and Xue-Yu LI for data discussion.

Conflicts of Interest: The authors declare no conflict of interest.

\section{References}

1. Corma, A.; Corresa, E.; Mathieu, Y.; Sauvanaud, L.; Al-Bogami, S.; Al-Ghrami, M.S.; Bourane, A. Crude oil to chemicals: Light olefins from crude oil. Catal. Sci. Technol. 2017, 7, 12-46. [CrossRef]

2. Marcilly, C. Evolution of refining and petrochemicals: What is the place of zeolites. Oil Gas Sci. Technol. 2001, 56, 499-514. [CrossRef]

3. Derrien, M.L. Chapter 18 Selective Hydrogenation Applied to the Refining of Petrochemical Raw Materials Produced by Steam Cracking. In Studies in Surface Science and Catalysis; Cerveny, L., Ed.; Elsevier: Amsterdam, The Netherlands, 1986; Volume 27, pp. $613-666$.

4. Puls, F.H.; Ruhnke, K.D. Butene-1 Containing Feed Purification Process (CS-165). U.S. Patent 4260840A, 7 April 1981.

5. Argyle, M.D.; Bartholomew, C.H. Heterogeneous catalyst deactivation and regeneration: A review. Catalysts 2015, 5, 145-269. [CrossRef]

6. Albers, P.; Pietsch, J.; Parker, S.F. Poisoning and deactivation of palladium catalysts. J. Mol. Catal. A Chem. 2001, 173, 275-286. [CrossRef]

7. Burger, B.J.; Thompson, M.E.; Cotter, W.D.; Bercaw, J.E. Ethylene insertion and. beta.-hydrogen elimination for permethylscandocene alkyl complexes. A study of the chain propagation and termination steps in Ziegler-Natta polymerization of ethylene. $J$. Am. Chem. Soc. 1990, 112, 1566-1577. [CrossRef]

8. Campos, K.R.; Cai, D.; Journet, M.; Kowal, J.J.; Larsen, R.D.; Reider, P.J. Controlled Semihydrogenation of Aminoalkynes Using Ethylenediamine as a Poison of Lindlar's Catalyst. J. Org. Chem. 2001, 66, 3634-3635. [CrossRef]

9. Lu, F.; Xu, Y.; Jiang, X.; Liu, Y.; Huang, J.; Sun, D. Biosynthesized Pd/ $\gamma$-Al2O3 catalysts for low-temperature 1,3-butadiene hydrogenation: The effect of calcination atmosphere. New J. Chem. 2017, 41, 13036-13042. [CrossRef]

10. Lu, F.; Sun, D.; Jiang, X. Plant-mediated synthesis of $\mathrm{AgPd} / \gamma-\mathrm{Al}_{2} \mathrm{O}_{3}$ catalysts for selective hydrogenation of 1,3-butadiene at low temperature. New J. Chem. 2019, 43, 13891-13898. [CrossRef]

11. Nikolaev, S.A.; Krotova, I.N. Partial hydrogenation of phenylacetylene over gold- and palladium-containing catalysts. Pet. Chem. 2013, 53, 394-400. [CrossRef]

12. Zhang, Q.; Li, J.; Liu, X.; Zhu, Q. Synergetic effect of $\mathrm{Pd}$ and $\mathrm{Ag}$ dispersed on $\mathrm{Al}_{2} \mathrm{O}_{3}$ in the selective hydrogenation of acetylene. Appl. Catal. A Gen. 2000, 197, 221-228. [CrossRef]

13. Studt, F.; Abild-Pedersen, F.; Bligaard, T.; Sørensen, R.Z.; Christensen, C.H.; Nørskov, J.K. Identification of non-precious metal alloy catalysts for selective hydrogenation of acetylene. Science 2008, 320, 1320-1322. [CrossRef]

14. Totarella, G.; Beerthuis, R.; Masoud, N.; Louis, C.; Delannoy, L.; de Jongh, P.E. Supported Cu Nanoparticles as Selective and Stable Catalysts for the Gas Phase Hydrogenation of 1,3-Butadiene in Alkene-Rich Feeds. J. Phys. Chem. C 2021, 125, 366-375. [CrossRef] [PubMed]

15. Zhao, W.; Brouri, D.; Casale, S.; Delannoy, L.; Louis, C. Exploration of the preparation of $\mathrm{Cu} / \mathrm{TiO}_{2}$ catalysts by depositionprecipitation with urea for selective hydrogenation of unsaturated hydrocarbons. J. Catal. 2016, 340, 95-106.

16. Shi, X.; Lin, Y.; Huang, L.; Sun, Z.; Yang, Y.; Zhou, X.; Vovk, E.; Liu, X.; Huang, X.; Sun, M.; et al. Copper Catalysts in Semihydrogenation of Acetylene: From Single Atoms to Nanoparticles. ACS Catal. 2020, 10, 3495-3504. [CrossRef]

17. Huang, F.; Deng, Y.; Chen, Y.; Cai, X.; Peng, M.; Jia, Z.; Xie, J.; Xiao, D.; Wen, X.; Wang, N.; et al. Anchoring Cu1 species over nanodiamond-graphene for semi-hydrogenation of acetylene. Nat. Commun. 2019, 10, 4431. [CrossRef] [PubMed]

18. Louis, C.; Delannoy, L. Chapter One-Selective hydrogenation of polyunsaturated hydrocarbons and unsaturated aldehydes over bimetallic catalysts. In Advances in Catalysis; Song, C., Ed.; Academic Press: Cambridge, MA, USA, 2019; Volume 64, pp. 1-88.

19. Xiaoke, H.; Xiaoyun, L.; Zhao, W.; Nian, H.; Zhao, D.; Lihua, C.; Baolian, S. Self-reduction for the Synthesis of Co Supported on Hierarchically Porous Carbon for Selective Hydrogenation Reaction. Chem. J. Chin. Univ. 2020, 41, 639-945. [CrossRef]

20. Wang, Z.; Wang, G.; Louis, C.; Delannoy, L. Bimetallic $\mathrm{Ni}-\mathrm{Zn} / \mathrm{TiO}_{2}$ catalysts for selective hydrogenation of alkyne and alkadiene impurities from alkenes stream. Res. Chem. Intermed. 2021, 47, 91-116. [CrossRef]

21. Cao, Y.; Zhang, H.; Ji, S.; Sui, Z.; Jiang, Z.; Wang, D.; Zaera, F.; Zhou, X.; Duan, X.; Li, Y. Adsorption Site Regulation to Guide Atomic Design of Ni-Ga Catalysts for Acetylene Semi-Hydrogenation. Angew. Chem. Int. Ed. 2020, 59, 11647-11652. [CrossRef] [PubMed]

22. Putro, W.S.; Kojima, T.; Hara, T.; Ichikuni, N.; Shimazu, S. Selective hydrogenation of unsaturated carbonyls by Ni-Fe-based alloy catalysts. Catal. Sci. Technol. 2017, 7, 3637-3646. [CrossRef]

23. Hu, Q.; Wang, S.; Gao, Z.; Li, Y.; Zhang, Q.; Xiang, Q.; Qin, Y. The precise decoration of Pt nanoparticles with Fe oxide by atomic layer deposition for the selective hydrogenation of cinnamaldehyde. Appl. Catal. B Environ. 2017, 218, 591-599. [CrossRef]

24. Wehrli, J.T.; Thomas, D.J.; Wainwright, M.S.; Trimm, D.L.; Cant, N.W. Selective hydrogenation of propyne over supported copper catalysts: Influence of support. Appl. Catal. 1991, 70, 253-262. [CrossRef]

25. Stammbach, M.; Thomas, D.; Trimm, D.; Wainwright, M. Hydrogenation of ethyne over an ion-exchanged copper on silica catalyst. Appl. Catal. 1990, 58, 209-217. [CrossRef] 
26. Ossipoff, N.J.; Cant, N. The hydrogenation and oligomerization of propyne over an ion-exchanged copper on silica catalyst. J. Catal. 1994, 148, 125-133. [CrossRef]

27. Sárkány, A.; Guczi, L.; Weiss, A.H. On the aging phenomenon in palladium catalysed acetylene hydrogenation. Appl. Catal. 1984, 10, 369-388. [CrossRef]

28. Sankar, M.; Dimitratos, N.; Miedziak, P.J.; Wells, P.P.; Kiely, C.J.; Hutchings, G.J. Designing bimetallic catalysts for a green and sustainable future. Chem. Soc. Rev. 2012, 41, 8099-8139. [CrossRef] [PubMed]

29. Delannoy, L.; Thrimurthulu, G.; Reddy, P.S.; Méthivier, C.; Nelayah, J.; Reddy, B.M.; Ricolleau, C.; Louis, C. Selective hydrogenation of butadiene over $\mathrm{TiO}_{2}$ supported copper, gold and gold-copper catalysts prepared by deposition-precipitation. Phys. Chem. Chem. Phys. 2014, 16, 26514-26527. [CrossRef] [PubMed]

30. McCue, A.J.; McRitchie, C.J.; Shepherd, A.M.; Anderson, J.A. Cu/ $\mathrm{Al}_{2} \mathrm{O}_{3}$ catalysts modified with Pd for selective acetylene hydrogenation. J. Catal. 2014, 319, 127-135. [CrossRef]

31. Boucher, M.B.; Zugic, B.; Cladaras, G.; Kammert, J.; Marcinkowski, M.D.; Lawton, T.J.; Sykes, E.C.H.; Flytzani-Stephanopoulos, M. Single atom alloy surface analogs in Pd $0.18 \mathrm{Cu} 15$ nanoparticles for selective hydrogenation reactions. Phys. Chem. Chem. Phys. 2013, 15, 12187-12196. [CrossRef] [PubMed]

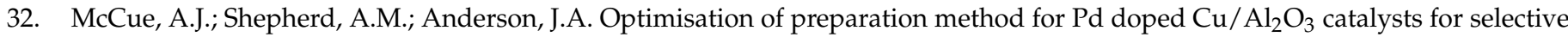
acetylene hydrogenation. Catal. Sci. Technol. 2015, 5, 2880-2890. [CrossRef]

33. Lucci, F.R.; Liu, J.; Marcinkowski, M.D.; Yang, M.; Allard, L.F.; Flytzani-Stephanopoulos, M.; Sykes, E.C.H. Selective hydrogenation of 1,3-butadiene on platinum-copper alloys at the single-atom limit. Nat. Commun. 2015, 6, 8550. [CrossRef]

34. Zhao, W.; Wang, G.; Louis, C.; Delannoy, L. Novel non-noble bimetallic Cu- $\mathrm{Zn} / \mathrm{TiO}_{2}$ catalysts for selective hydrogenation of butadiene. J. Catal. 2017, 347, 185-196.

35. Zhao, Y.; Guo, Z.; Zhang, H.; Peng, B.; Xu, Y.; Wang, Y.; Zhang, J.; Xu, Y.; Wang, S.; Ma, X. Hydrogenation of diesters on copper catalyst anchored on ordered hierarchical porous silica: Pore size effect. J. Catal. 2018, 357, 223-237. [CrossRef]

36. Hu, N.; Li, X.-Y.; Liu, S.-M.; Wang, Z.; He, X.-K.; Hou, Y.-X.; Wang, Y.-X.; Deng, Z.; Chen, L.-H.; Su, B.-L. Enhanced stability of highly-dispersed copper catalyst supported by hierarchically porous carbon for long term selective hydrogenation. Chin. J. Catal. 2020, 41, 1081-1090. [CrossRef]

37. Su, B.L.; Vantomme, A.; Surahy, L.; Pirard, R.; Pirard, J.P. Hierarchical Multimodal Mesoporous Carbon Materials with Parallel Macrochannels. Chem. Mater. 2007, 19, 3325-3333. [CrossRef]

38. Yuan, Z.Y.; Ren, T.Z.; Azioune, A.; Pireaux, J.J.; Su, B.L. Self-Assembly of Hierarchically Mesoporous-Macroporous Phosphated Nanocrystalline Aluminum (Oxyhydr)oxide Materials. Chem. Mater. 2006, 18, 1753-1767. [CrossRef]

39. Dapsens, P.Y.; Hakim, S.H.; Su, B.-L.; Shanks, B.H. Direct observation of macropore self-formation in hierarchically structured metal oxides. Chem. Commun. 2010, 46, 8980-8982. [CrossRef]

40. Zanella, R.; Delannoy, L.; Louis, C. Mechanism of deposition of gold precursors onto TiO $\mathrm{during}_{2}$ the preparation by cation adsorption and deposition-precipitation with NaOH and urea. Appl. Catal. A Gen. 2005, 291, 62-72. [CrossRef]

41. Cychosz, K.A.; Guillet-Nicolas, R.; García-Martínez, J.; Thommes, M. Recent advances in the textural characterization of hierarchically structured nanoporous materials. Chem. Soc. Rev. 2017, 46, 389-414. [CrossRef]

42. Chen, M.; Wang, J.; Jiang, B.; Yang, Y. Diffusion measurements of isopentane, 1-hexene, cyclohexane in polyethylene particles by the intelligent gravimetric analyzer. J. Appl. Polym. Sci. 2013, 127, 1098-1104. [CrossRef]

43. Huang, H.H.; Yan, F.Q.; Kek, Y.M.; Chew, C.H.; Xu, G.Q.; Ji, W.; Oh, P.S.; Tang, S.H. Synthesis, Characterization, and Nonlinear Optical Properties of Copper Nanoparticles. Langmuir 1997, 13, 172-175. [CrossRef]

44. Condorelli, G.G.; Costanzo, L.L.; Fragalà, I.L.; Giuffrida, S.; Ventimiglia, G. A single photochemical route for the formation of both copper nanoparticles and patterned nanostructured films. J. Mater. Chem. 2003, 13, 2409-2411. [CrossRef]

45. Savinova, E.R.; Chuvilin, A.L.; Parmon, V.N. Copper colloids stabilized by water-soluble polymers: Part I. Preparation and properties. J. Mol. Catal. 1988, 48, 217-229. [CrossRef]

46. Derrouiche, S.; La Fontaine, C.; Thrimurtulu, G.; Casale, S.; Delannoy, L.; Lauron-Pernot, H.; Louis, C. Unusual behaviour of $\mathrm{Au} / \mathrm{ZnO}$ catalysts in selective hydrogenation of butadiene due to the formation of a AuZn nanoalloy. Catal. Sci. Technol. 2016, 6, 6794-6805. [CrossRef]

47. Miyazaki, M.; Furukawa, S.; Takayama, T.; Yamazoe, S.; Komatsu, T. Surface Modification of PdZn Nanoparticles via Galvanic Replacement for the Selective Hydrogenation of Terminal Alkynes. ACS Appl. Nano Mater. 2019, 2, 3307-3314. [CrossRef]

48. Sun, M.-H.; Huang, S.-Z.; Chen, L.-H.; Li, Y.; Yang, X.-Y.; Yuan, Z.-Y.; Su, B.-L. Applications of hierarchically structured porous materials from energy storage and conversion, catalysis, photocatalysis, adsorption, separation, and sensing to biomedicine. Chem. Soc. Rev. 2016, 45, 3479-3563. [CrossRef]

49. Wang, Z. Selective Hydrogenation of Butadiene over Non-Noble Bimetallic Catalysts. (Catalyseurs Bimétalliques à Base de Métaux Non Nobles Pour L'hydrogénation Sélective du Butadiène-Paris VI). Ph.D. Thesis, Université Pierre et Marie Curie, Paris, France, 2017.

50. Wiame, F.; Islam, M.M.; Salgın, B.; Światowska, J.; Costa, D.; Diawara, B.; Maurice, V.; Marcus, P. Zn effect on STM imaging of brass surfaces. Surf. Sci. 2016, 644, 148-152. [CrossRef]

51. Krajčí, M.; Hafner, J. Intermetallic Compounds as Selective Heterogeneous Catalysts: Insights from DFT. ChemCatChem 2016, 8, 34-48. [CrossRef] 
52. Bridier, B.; López, N.; Pérez-Ramírez, J. Molecular understanding of alkyne hydrogenation for the design of selective catalysts. Dalton Trans. 2010, 39, 8412-8419. [CrossRef] [PubMed]

53. Berteau, P.; Ceckiewicz, S.; Delmon, B. Role of the acid-base properties of aluminas, modified $\gamma$-alumina, and silica-alumina in 1-butanol dehydration. Appl. Catal. 1987, 31, 361-383. [CrossRef]

54. Hugon, A.; Delannoy, L.; Louis, C. Supported gold catalysts for selective hydrogenation of 1,3-butadiene in the presence of an excess of alkenes. Gold Bull. 2008, 41, 127-138. [CrossRef]

55. Catillon-Mucherie, S.; Ammari, F.; Krafft, J.-M.; Lauron-Pernot, H.; Touroude, R.; Louis, C. Preparation of Coimpregnated $\mathrm{Cu}-\mathrm{Zn} / \mathrm{SiO}_{2}$ Catalysts: Influence of the Drying Step on Metallic Particle Size and on Cu0-ZnII Interactions. J. Phys. Chem. C 2007, 111, 11619-11626. [CrossRef] 